\title{
Plant Morphological, Physiological and Anatomical Adaption to Flooding Stress and the Underlying Molecular Mechanisms
}

\author{
Weitao Jia, Maohua Ma, Jilong Chen and Shengjun Wu*
}

Citation: Jia, W.; Ma, M.; Chen, J.; $\mathrm{Wu}$, S. Plant Morphological, Physiological and Anatomical Adaption to Flooding Stress and the Underlying Molecular Mechanisms. Int. J. Mol. Sci. 2021, 22, 1088. https://doi.org/10.3390/ijms22031088

Academic Editor: Giampiero Cai Received: 18 December 2020

Accepted: 19 January 2021

Published: 22 January 2021

Publisher's Note: MDPI stays neutral with regard to jurisdictional claims in published maps and institutional affiliations.

Copyright: (c) 2021 by the authors. Licensee MDPI, Basel, Switzerland. This article is an open access article distributed under the terms and conditions of the Creative Commons Attribution (CC BY) license (https:// creativecommons.org/licenses/by/ $4.0 /)$.
Chongqing Institute of Green and Intelligent Technology, Chinese Academy of Sciences, Chongqing 400714, China; jiawt@cigit.ac.cn (W.J.); mamaohua@cigit.ac.cn (M.M.); chenjilong@cigit.ac.cn (J.C.)

* Correspondence: wsj@cigit.ac.cn; Tel.: +86-10-65935912

\begin{abstract}
Globally, flooding is a major threat causing substantial yield decline of cereal crops, and is expected to be even more serious in many parts of the world due to climatic anomaly in the future. Understanding the mechanisms of plants coping with unanticipated flooding will be crucial for developing new flooding-tolerance crop varieties. Here we describe survival strategies of plants adaptation to flooding stress at the morphological, physiological and anatomical scale systemically, such as the formation of adventitious roots (ARs), aerenchyma and radial $\mathrm{O}_{2}$ loss (ROL) barriers. Then molecular mechanisms underlying the adaptive strategies are summarized, and more than thirty identified functional genes or proteins associated with flooding-tolerance are searched out and expounded. Moreover, we elaborated the regulatory roles of phytohormones in plant against flooding stress, especially ethylene and its relevant transcription factors from the group VII Ethylene Response Factor (ERF-VII) family. ERF-VIIs of main crops and several reported ERF-VIIs involving plant tolerance to flooding stress were collected and analyzed according to sequence similarity, which can provide references for screening flooding-tolerant genes more precisely. Finally, the potential research directions in the future were summarized and discussed. Through this review, we aim to provide references for the studies of plant acclimation to flooding stress and breeding new flooding-resistant crops in the future.
\end{abstract}

Keywords: flooding; morphology; physiology; anatomy; molecular mechanisms; phytohormone

\section{Introduction}

Along with climate changes, flooding shows a heavier tendency triggering severe crop reduction in both yield and quality around the world [1]. In the United States, for instance, losses of crop yield induced by flooding followed by drought from 2000 to 2011 [2]. In 2016, a total of 217 million dollars was paid for damages or controls associated with flooding, which cost 3.4 times higher than that for droughts (www.rma.usda.gov/data/cause). In some developing countries, because of their poor drainage systems, the impact of frequent flooding on crop systems is more serious, which usually aggravates poverty and food insecurity [1]. To reduce the losses, it is essential to unravel the mechanisms of plants against flooding stress for developing new flooding-tolerance crops.

Generally, flooding can be classified into two forms depending on water depth: waterlogging and submergence $[3,4]$. Waterlogging is the condition that water exists on the soil surface and only plant roots are surrounded by water, while submergence is the state that the whole plant partially or completely immerses in water $[3,5,6]$. One of the immediate impacts caused by flooding is the deficiency of oxygen [7,8]. Previous studies showed that oxygen diffused in water approximately 10,000 times slower than that in air, and oxygen permeating into water-immersed soil is about 320,000 times less than that into soil full of gas $[3,9,10]$. The deficiency of oxygen in soil restricts plant growth resulting in the reduction of crop yield $[3,11]$. Under waterlogging stress, the growth of the plant was impeded due to enhanced anaerobic respiration $[3,11]$. Meanwhile, adventitious roots (ARs), aerenchyma and radial $\mathrm{O}_{2}$ loss (ROL) barriers emerged in roots for the exchange of 
gas $[3,11]$. When exposed to submergence stress, plants have evolved two main strategies to resist the adversity: low oxygen quiescence syndrome (LOQS) for complete submergence and low oxygen escape syndrome (LOES) for partial submergence [8,12]. Plants with LOQS strategy demonstrate restricted growth through keeping the minimum energy and carbon consumptions for prolonging underwater survival [13] (Figure 1A). After the flooding recedes, these plants can be recovered rapidly [11]. Escaping from water (LOES) is another strategy that plants maintain the upper leaves in the aerial environment for getting adequate oxygen, light and carbon dioxide [8,11]. Accordingly, several morphology and anatomical traits of plants change with the water depth, such as deepwater rice and Rumex palustris with internode or petiole elongation as well as aerenchyma formation [14-16] (Figure 1A).

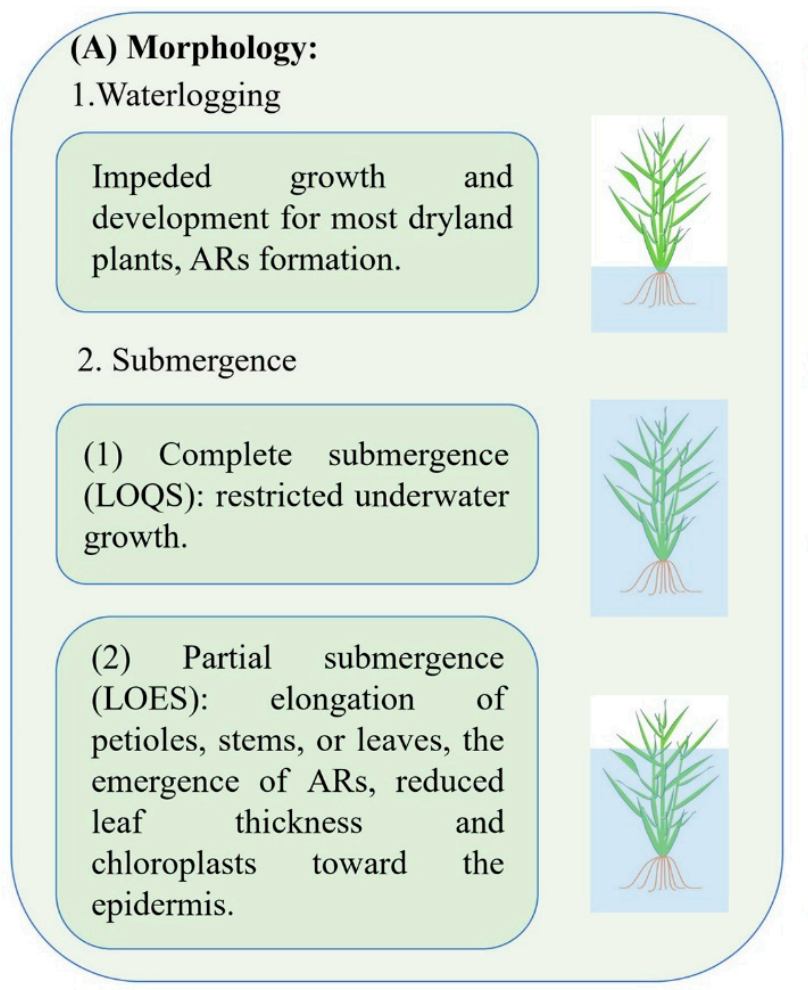

\section{(B) Physiology:}

1. ROS accumulation and scavenging.

2. Photosynthesis: the less availability of $\mathrm{O}_{2}, \mathrm{CO}_{2}$ or light limited the photosynthesis rates.

3. Energy metabolism: highly energy consumptive, increased anaerobic respiration.

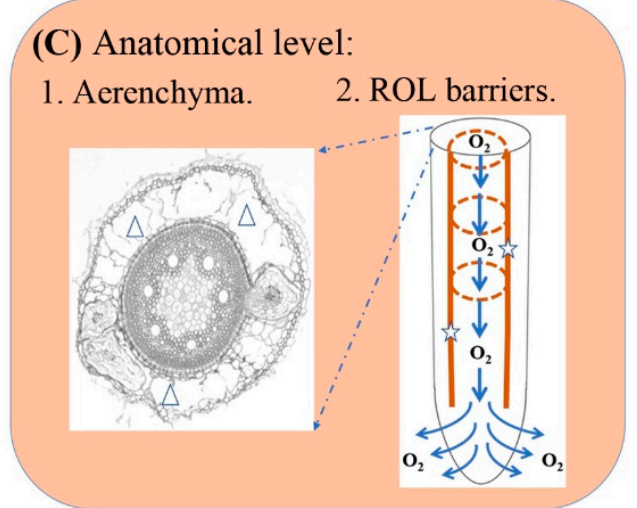

Figure 1. Response and the adaptive mechanisms of plants under flooding (hypoxic) stress. (A) Plants morphology under waterlogging and submergence stress. (B) The physiological changes of plants in response to flooding stress. (C) The main anatomical characteristics of plants adaptation to flooding stress. Triangles and pentagrams point to the location of aerenchyma and radial $\mathrm{O}_{2}$ loss (ROL) barriers respectively.

Recently, much progress has been made in the mechanisms of plant acclimation to flooding stress [17-19]. For example, Nagai et al. reported two genes controlled internode elongation antagonistically in rice, the 'accelerator' ACCELERATOR OF INTERNODE ELONGATION 1 (ACE1) and the 'decelerator' DECELERATOR OF INTERNODE ELONGATION 1 (DEC1) [18]. Tang et al. showed that two transcription factors of the WRKY family (WRKY33 and WRKY12) interacted with each other to up-regulate RAP2.2 for Arabidopsis adaptation to submergence stress [19]. Bui et al. reported that transcription factor ANAC017 mediated differential submergence tolerance of Arabidopsis between juvenile and adult stages [20]. These studies contribute to our understanding of the mechanisms of plant adaptation to flooding stress, however, the detailed update including these latest research progresses has not been conducted subsequently. In this review, plant survival strategies under flooding stress in morphology, physiology and anatomy levels were investigated and exhibited initially, then the potential crucial genes or proteins and the regulatory role of phytohormones were summarized by highlighting the most recent 
findings of plant adapting to flooding stress. Moreover, several key open questions worthy of further study were proposed and discussed.

\section{Plant Responses to Flooding Stress}

Flooding is a natural occurrence with adverse effects on plant growth and development, multiple mechanisms of plants adaption to flooding stress have been discovered at morphology, physiological and anatomical scales.

\subsection{The Morphology of Plants under Flooding Stress}

Generally, flooding stress triggers adaptive changes in plant roots and shoots at a morphological scale, such as the formation of ARs, the growth of the shoots inhibited or accelerated (Figure 1A). Previously, some important crops including wheat, maize, rice and soybean have been studied in their responses to flooding stress. For instance, wheat, as a dryland crop, was sensitive to flooding stress [21]. When exposed to waterlogging stress, dry mass of wheat shoot and root, and the ratio of root/shoot significantly declined compared to controls, indicating that root growth was inhibited more seriously than shoot [22,23]. Maize was also intolerant against waterlogging stress and the trefoil stage was the most sensitive period for maize [24,25]. Waterlogging inhibited maize growth resulting in decline in plant height, ear height, dry weight, leaf area index and grain characteristics (such as grain number per ear and 1000-grain weight) [26]. Meanwhile, contents of chlorophyll, soluble sugar and starch in leaves, stems and roots decreased under waterlogging stress [27]. For rice, many lowland cultivars are susceptible to submergence stress and thus hardly survive as the deluge lasts for a longer period of time [3,28,29]. However, several rice cultivars can experience flash-flood (complete submergence) for around two weeks by restricting shoot elongation as well as carbohydrate consumption, and will be recovered once the flash-flood recedes [5,11]. On the other hand, deepwater rice, which adapts to the submergence where it grows, is able to maintain the top leaves in the aerial environment for catching sufficient oxygen by elongating its internodes rapidly $[5,30,31]$. The growth and grain yield of soybean is also affected by flooding [32]. At the seedling stage, root growth of soybean was suppressed severely after submergence prolonging for 10 days [33]. Different soybean genotypes might utilize distinct mechanisms to resist waterlogging stress and proteins associated with energy metabolism were thought to function in soybeans tolerance to flooding stress $[34,35]$. Generally, waterlogging stress enhances anaerobic respiration of roots of dryland plants along with energy consumption and restricts their growth eventually. Likewise, complete submergence stress inhibits the growth of plants and decreases the rate of survival with the extension of the submergence time in most cases. By contrast, partial submergence promotes the elongation of internode, petiole or other organs in some plant species for getting enough oxygen, which contributes to their rapid growth in a short time.

Adventitious roots, as a typical trait of plants acclimating to waterlogging stress, can facilitate the uptake of water and nutrient as well as the transport of gas more effectively [36] (Table 1). ARs can be developed from some non-root tissues of the plants during normal development, or under the stimulation of external stresses, including flooding, nutrient deficiency, heavy metals and wounding [37]. On the basis of physical characteristics and generation conditions, ARs can be divided into various types, such as hypocotyl roots, crown roots, brace roots, nodal roots, stem roots, junction roots and prop roots, among which the front five types can be triggered by flooding [37]. When exposed to waterlogging stress, maize formed more crown roots than controls and the waterloggingtolerant line possessed more crown roots than the waterlogging-sensitive line [38]. In deepwater rice, the elongation of ARs was initiated after 8 to $10 \mathrm{~h}$ under partial submergence stress, and ethylene was found to facilitate the formation of ARs through triggering the death of epidermal cells covering the root tip [39,40]. In tomato, ARs gradually formed at the hypocotyl after three days of partial submergence, and further extended to the upper surface of the water along caulicles [41]. Furthermore, inhibiting ethylene or auxin 
production impaired ARs formation of tomato, which indicated that ethylene and auxin might interact with each other during the development of ARs under flooding stress [42]. Likewise, a recent study reported that waterlogging stress-induced cucumber generating a large amount of ARs, and both auxin and ethylene can stimulate the formation of ARs, however, auxin-induced ARs relied on ethylene while ethylene-induced ARs was unaffected by auxin [43]. Contrastively, the opposite result was found in Rumex palustris that auxin-induced ARs were not affected by inhibiting ethylene biosynthesis while the inhibition of auxin transport suppressed ethylene-induced ARs formation [44]. In summary, the formation of plant ARs is mainly regulated by ethylene and auxin under flooding stress, however, their roles may be diverse in different plants.

\subsection{The Physiological Phenotype of Plants Response to Flooding Stress}

Flooding stress leads to accumulation of the harmful substances in plants, such as reactive oxygen species (ROS) and malondialdehyde (MDA) [67]. In turn, plants activate the internal protection mechanisms to scavenge these components, such as the production of proline, glutathione and the activation of antioxidant enzymes [57,68,69] (Figure 1B, Table 2). ROS are toxic byproducts of oxidative metabolisms, such as $\mathrm{O}_{2} \cdot{ }^{-}, \mathrm{H}_{2} \mathrm{O}_{2}, \mathrm{OH}^{-}$ and ${ }^{1} \mathrm{O}_{2}[70,71]$. Whereas, ROS also functions as signal molecules that regulate plant development under environmental stresses [56,71]. Submergence exhibited a huge impact on ROS homeostasis. Ye et al. reported that submergence led to a decrease of $\mathrm{H}_{2} \mathrm{O}_{2}$ content in bermudagrass (Cynodon dactylon) leaves, though $\mathrm{O}_{2} \cdot{ }^{-}$content had insignificant change [68]. Contrastively, another study showed that $\mathrm{O}_{2} \cdot{ }^{-}$and $\mathrm{H}_{2} \mathrm{O}_{2}$ concentration in the elongation and mature zone of barley roots increased under waterlogging stress [72]. Additionally, MDA content in bermudagrass leaves increased after submergence for three weeks and catalase (CAT), glutathione reductase (GR) and peroxidase (POD) activities presented an upward trend with the extension of the time [68]. Wang et al. showed the activities of antioxidative enzymes POD and superoxide dismutase (SOD) in roots of Triarrhena sacchariflora increased first and then decreased under flooding stress as well as contents of proline and MDA compared with control plants [69].

On the other hand, flooding is accompanied by the deprivation of oxygen, which leads to aerobic respiration in a low-level and accelerates more carbohydrates consumed by glycolysis [85]. Moreover, under complete submergence stress, the insufficiency of carbon dioxide and light decreased plant photosynthesis rates [13,86] (Figure 1B). For instance, the accumulation of soluble sugar and sucrose in bermudagrass leaves declined obviously under submergence stress [68]. Loreti et al. reported that starch content in rosette leaves of Arabidopsis degraded with the extension of submerged time during the night, and glucose content was observed decline at the end of the night as well as sucrose [87]. For spring maize, the negative impact induced by waterlogging stress was different because of the distinction of duration and growth stage, and the seedling stage was the sensitive period followed by the jointing and tasseling stages [88]. Additionally, the photosynthetic rate (Pn) decreased with the waterlogging time prolonging and resulted in the reduction of total dry weight and grain yield ultimately [88]. 
Table 1. The formation of adventitious roots (ARs), aerenchyma and ROL barriers in plants responding to flooding stress.

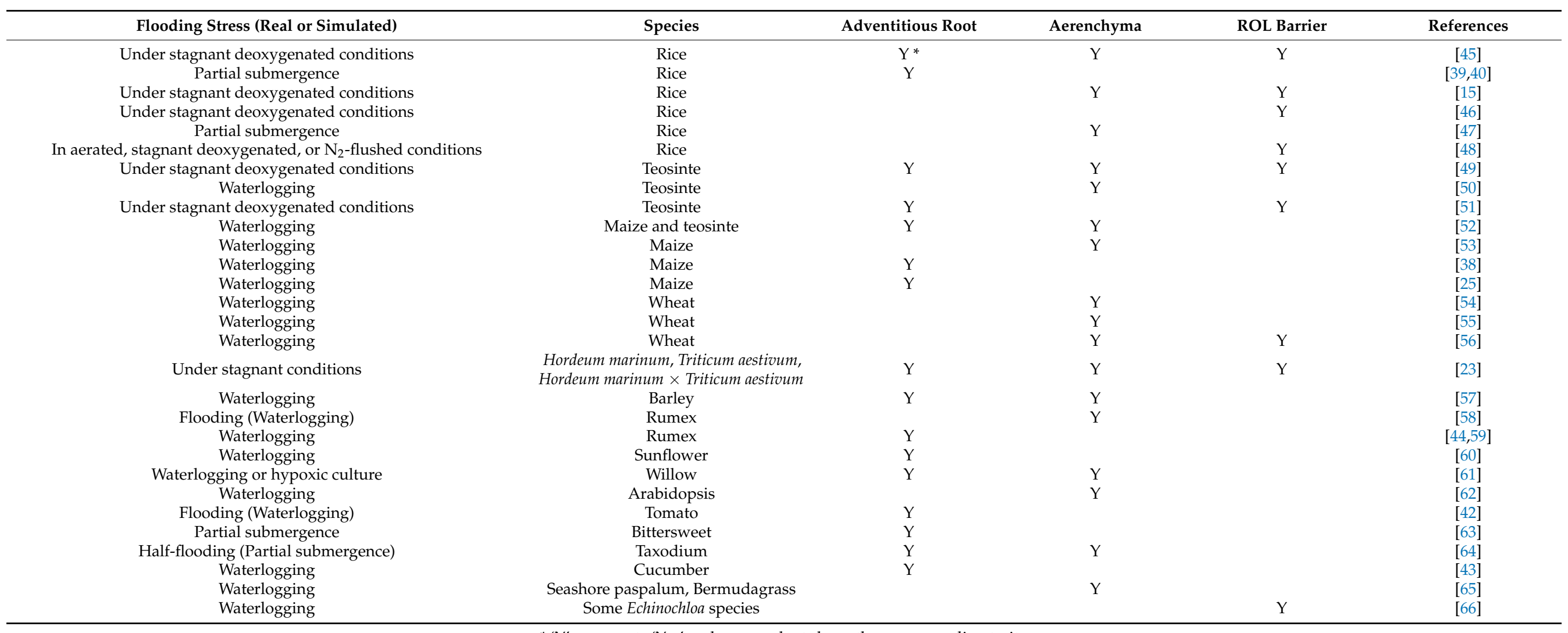

* ' $Y$ ' represents 'Yes' and means plants have the corresponding trait. 
Table 2. Changes of ROS, antioxidant enzymes and other physiologic indexes in plant tissues as exposed to flooding stress.

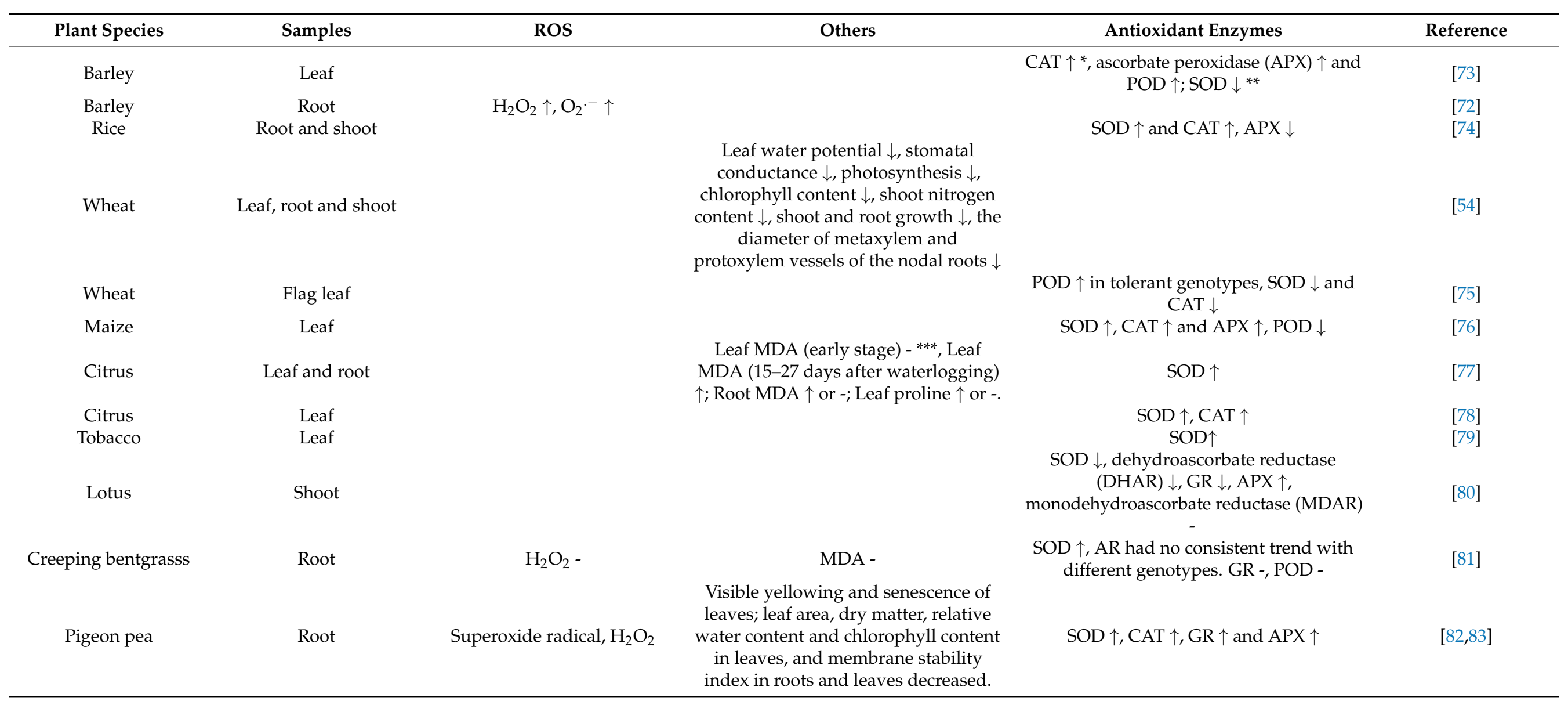


Table 2. Cont.

\begin{tabular}{|c|c|c|c|c|c|}
\hline Plant Species & Samples & ROS & Others & Antioxidant Enzymes & Reference \\
\hline Bermudagrass & Leaf & $\mathrm{H}_{2} \mathrm{O}_{2} \downarrow, \mathrm{O}_{2} \cdot-$ & Proline - & $\mathrm{POD} \uparrow, \mathrm{GR} \uparrow, \mathrm{CAT} \uparrow$ & [68] \\
\hline Perennial ryegrass & Shoot and root & & $\begin{array}{c}\text { Leaf chlorophyll and total carotenoid } \downarrow \text {, } \\
\text { water-soluble carbohydrate (shoots } \\
\text { and roots) } \downarrow \text {, MDA } \uparrow\end{array}$ & $\begin{array}{c}\text { CAT and POD (shoot) } \uparrow, \text { SOD, CAT, POD } \\
\text { and APX (root) } \downarrow\end{array}$ & [84] \\
\hline Soybean & Leaf & $\begin{array}{l}\mathrm{H}_{2} \mathrm{O}_{2} \text { content increased at } 7 \\
\text { days of waterlogging. }\end{array}$ & $\begin{array}{l}\text { Activities of lactate dehydrogenase } \\
\text { (LDH), alanine aminotransferase } \\
\text { (AlaAT), alcohol dehydrogenase } \\
\text { (ADH) and pyruvate decarboxylase } \\
\text { (PDC) changed inconsistently in } \\
\text { different genotypes under } \\
\text { waterlogging stress. }\end{array}$ & $\begin{array}{l}\text { SOD activity increased after } 7 \text { days of } \\
\text { waterlogging, APX and CAT activities } \\
\text { changed with no consistent trend among } \\
\text { different genotypes or conditions. }\end{array}$ & [35] \\
\hline
\end{tabular}

* ‘ $\uparrow^{\prime}$ represents 'increase'; ;** ' $\downarrow$ ' represents 'decrease'; ;** ‘-' represents 'no change'. 


\subsection{Anatomical Adaptations to Flooding Stress}

Flooding often leads to oxygen deprivation in soils and plant roots, which significantly restricts metabolic activities for plant survival and development. Therefore, amounts of aerenchyma and ROL barriers in plant roots are formed to transport adequate oxygen from shoots to roots (Figure 1C).

\subsubsection{The Formation of Aerenchyma}

Aerenchyma not only exists in many plants constitutively, but also is formed inductively by environmental stress, such as flooding stress [89] (Table 1). It forms in roots and shoots and consists of thin-walled cells filled with gas spaces to facilitate the diffusion of oxygen [8]. For instance, Aerenchyma formed in the mid-cortex cells of wheat roots after waterlogging for $24 \mathrm{~h}$ and its formation was mediated by ROS $[55,56]$. When applied with an ethylene precursor beforehand, wheat seedlings formed lysigenous aerenchyma in roots and these aerenchyma were further developed under hypoxic stress [90]. Zea nicaraguensis is a wild relative of maize and grew in frequently flooded areas [49]. Soil waterlogging increased aerenchyma proportion in the cross-sectional area of maize root from less than $1 \%$ in drained soil to $15 \%$ as well as from $22 \%$ to $29 \%$ in Z. nicaraguensis roots [49]. Another study reported that ARs of waterlogging-tolerant barley (Hordeum vulgare L.) genotypes exhibited remarkably higher porosity and formed aerenchyma more quickly compared to sensitive ones [57]. Aerenchyma increases plant tolerance to flooding stress by improving the oxygen-transport efficiency from shoot to root tip, and its formation mainly relies on ethylene and ROS signaling.

\subsubsection{A Barrier to Radial Oxygen Loss}

Except for aerenchyma, the oxygen-transport efficiency from shoot to root tip depends on another crucial factor, the formation of ROL barriers. ROL barriers usually form in the roots of waterlogging-tolerant plants, and can reduce oxygen leakage during its transport from shoot-to-root tip and impede soil phytotoxin entry simultaneously [49,51]. The ROL barriers can be formed constitutively or induced by stagnant conditions, such as flooding stress [14,91] (Figure 1C, Table 1). Many wetland species, such as Oryza sativa, Juncus effusus, Phragmites australis and Glyceria maxima, have been reported forming ROL barriers in roots $[14,15,92,93]$. For example, growing in stagnant nutrient solution with oxygen removal enhanced the development of ROL barriers in ARs of rice [15,45]. Long ARs of rice initiated the formation of ROL barriers quickly and developed well within $24 \mathrm{~h}$ under hypoxic conditions, however, short roots generated the barrier for more than $48 \mathrm{~h}$ [93]. The dryland species have the ability to form ROL barriers under flooding stress. For instance, seminal roots of wheat induced ROL barriers when exposed to waterlogging to enhance the internal supply of oxygen [56]. Notably, some Echinochloa species even developed a ROL barrier constitutively under aerated conditions [66].

The formation of ROL barriers can also be triggered by the organic acids [94,95]. In waterlogged soils, some monocarboxylic acids are produced by anaerobic microorganisms, such as acetic, butyric, hexanoic and propionic acids, which inhibit plant growth as accumulated to some extent and can invoke enhanced suberization or lignification in cell walls of roots $[96,97]$. For example, the ROL barrier in Hordeum marinum roots was induced by butyric and hexanoic acids individually or a mixture with acetic and propionic acids [94], and these four organic acids also triggered the ROL barrier in roots of rice [95].

\section{Molecular Mechanism of Plant Response to Flooding Stress}

On the basis of the morphology, physiology and anatomy characteristics of plant response to flooding stress, many associated-genes functioning in plant adaption to flooding stress have been reported and studied (Table 3). 


\subsection{The Formation of Adventitious Roots}

The emergence of ARs is one of the adaptive strategies for plants coping with flooding stress, and several genes have been identified to mediate ARs formation (Figure 2). GNOM encodes a guanine-nucleotide exchange factor for ADP-ribosylation factor (ARF) [120] and can influence polar auxin transport in plants [121,122]. Studies have reported that OsGNOM1 in rice affected the development of ARs through regulating polar auxin transport, and loss function of this gene resulted in the defect of ARs formation [120]. CsARN6.1 in cucumber encoded an AAA ATPase domain-containing protein and affected waterlogging tolerance through the regulation of ARs formation, besides, the transformation of CsARN6.1 from waterlogging-tolerant cultivar into waterlogging-sensitive variety increased numbers of ARs under waterlogging conditions [117]. Ethylene can induce ARs formation and this process requires ROS as a signal triggering programmed cell death in cortex cells [123,124]. For instance, waterlogging led to the accumulation of ethylene and ROS in cucumber, ethylene-induced AR formation was inhibited by the reduction of $\mathrm{H}_{2} \mathrm{O}_{2}$ [43]. The above results suggest that auxin, ethylene and ROS are required for the formation of ARs under flooding stress, but the mechanisms of interaction among them need to be revealed.

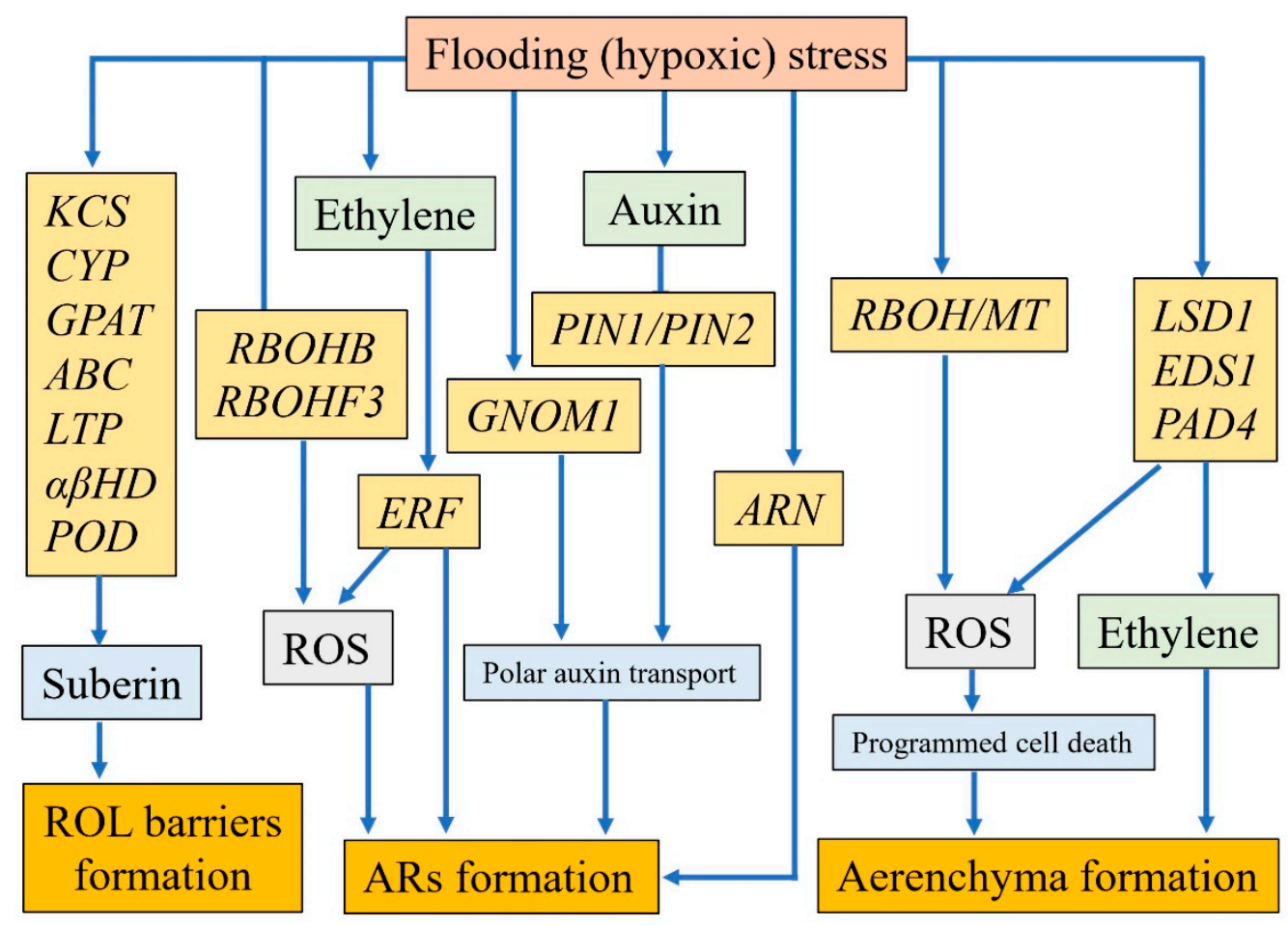

Figure 2. The molecular mechanisms of ROL barriers, ARs and aerenchyma formation. Researches about the formation of flooding-induced ROL barriers at the molecular level are relatively deficient, however, suberin has been considered to contribute to the formation of ROL barriers and genes (such as KCS, CYP, GPAT, ABC, LTP, $\alpha \beta H D, P O D$ ) involved in suberin biosynthesis may function in this process [48]. For ARs formation, flooding (hypoxic) stress can induce expressions of $R B O H B, R B O H F 3$, some Ethylene Response Factor (ERF) genes and ARN, then affects ARs formation directly or through ROS regulation $[25,43,117]$. Plants also can influence the development of ARs by mediating auxin polar transport through the activation of some auxin associated genes, such as GNOM1, PIN1 and PIN2 [120,125,126]. Aerenchyma formation depends on the accumulation of ROS. $R B O H$ for the generation of ROS and MT for ROS scavenging play important roles in this process [53]. In addition, genes LSD1, EDS1 and PAD4, which control the generation of ethylene and ROS in the upstream, are also involved in the formation of aerenchyma [62]. 
Table 3. General descriptions of recently reported genes and the relative phytohormones involved in plant response to flooding stress.

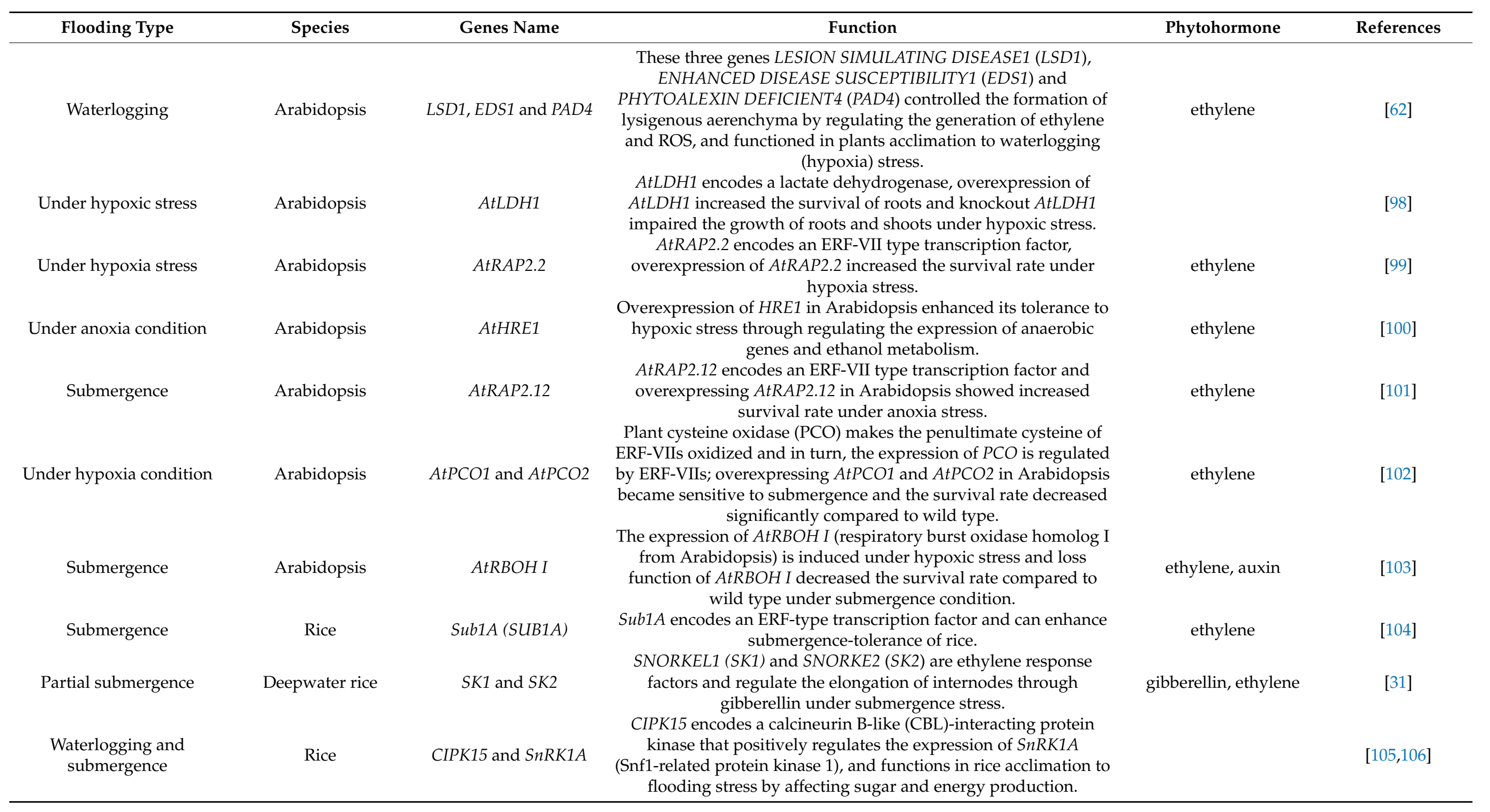


Table 3. Cont.

\begin{tabular}{|c|c|c|c|c|c|}
\hline Flooding Type & Species & Genes Name & Function & Phytohormone & References \\
\hline $\begin{array}{l}\text { Under anaerobic } \\
\text { condition }\end{array}$ & Rice & Amy3 subfamily genes & $\begin{array}{l}\text { Amy3 subfamily genes encode } \alpha \text {-amylases and their expression can } \\
\text { be induced in rice embryos by anaerobic conditions, which } \\
\text { contributes rice to survive under submerged conditions. }\end{array}$ & & [106] \\
\hline $\begin{array}{l}\text { Under anaerobic } \\
\text { condition }\end{array}$ & Rice & OsTPP7 & $\begin{array}{l}\text { OsTPP7 encodes a trehalose-6-phosphate (TP6) phosphatase and } \\
\text { facilitates rice germination under anaerobic conditions by } \\
\text { regulating local T6P/sucrose ratios. }\end{array}$ & & [107] \\
\hline Submergence & Rice & OsEREBP1 & $\begin{array}{l}\text { OsEREBP1 encodes an ERF transcription factor and may enhance } \\
\text { the submergence tolerance through regulating jasmonate and } \\
\text { abscisic acid signals. }\end{array}$ & jasmonate, abscisic acid & [108] \\
\hline Submergence & Rice & LGF1 & $\begin{array}{c}\text { LGF1 controlled the formation of leaf gas films and affected the } \\
\text { synthesis of C30 primary alcohol, which ultimately improved } \\
\text { submergence-tolerance of rice with increased } \\
\text { underwater photosynthesis. }\end{array}$ & & [109] \\
\hline Submergence & Deepwater rice & SD1 & $\begin{array}{l}\text { SD1 (SEMIDWARF1) encodes a gibberellin biosynthesis gene, it } \\
\text { can promote internodes elongation by increasing synthesis of } \\
\text { gibberellins and is regulated by a transcription factor OsEIL1a. }\end{array}$ & gibberellin, ethylene & [110] \\
\hline Submergence & Rice & OsARD1 & $\begin{array}{c}\text { OsARD1 encodes an acireductone dioxygenase (ARD) and } \\
\text { mediates the biosynthesis of an initial substrate methionine in the } \\
\text { process of ethylene synthesis. Overexpression of OsARD1 } \\
\text { increased the production of internal ethylene and } \\
\text { submergence-tolerance of transgenic lines was } \\
\text { improved simultaneously. }\end{array}$ & ethylene & [111] \\
\hline $\begin{array}{l}\text { Waterlogging and } \\
\text { submergence }\end{array}$ & Deepwater rice & $A C E 1$ and $D E C 1$ & $\begin{array}{l}A C E 1 \text { confers the intercalary meristematic cells with the division } \\
\text { ability and therefore regulated the elongation of internodes } \\
\text { together with GA; DEC1 restricts internodes elongation. }\end{array}$ & gibberellin & [18] \\
\hline Submergence & Maize & Subtol6 & $\begin{array}{c}\text { Subtol6 is a major QTL that can explain } 22 \% \text { of the phenotypic } \\
\text { differences in submergence tolerance within the recombinant } \\
\text { inbred lines. }\end{array}$ & & [112] \\
\hline Waterlogging & Maize & ZmEREB180 & $\begin{array}{c}\text { ZmEREB180 encodes an ERFV-II transcription factor from maize; } \\
\text { overexpression of ZmEREB180 increased the survival rate under } \\
\text { waterlogging stress through promoting ARs formation and } \\
\text { regulating antioxidant activities. }\end{array}$ & ethylene & [25] \\
\hline
\end{tabular}


Table 3. Cont.

\begin{tabular}{|c|c|c|c|c|c|}
\hline Flooding Type & Species & Genes Name & Function & Phytohormone & References \\
\hline Waterlogging & Wheat & TaERFVII.1 & $\begin{array}{l}\text { TaERFVII.1 belongs to ERF-VII family and functions in } \\
\text { waterlogging-tolerance of wheat, overexpression of TaERFVII.1 } \\
\text { increased the survival rate under waterlogging stress. }\end{array}$ & ethylene & [17] \\
\hline Waterlogging & Barley & HvERF2.11 & $\begin{array}{c}\text { The expression of HvERF2.11 can be induced by waterlogging and } \\
\text { mediated waterlogging-tolerance of plants through improving } \\
\text { some antioxidant and ADH enzymes activities. }\end{array}$ & ethylene & [113] \\
\hline Waterlogging & Actinidia deliciosa & $A d P D C 1$ & $\begin{array}{l}\text { AdPDC1 encodes a pyruvate decarboxylase which catalyzes the } \\
\text { first step in ethanolic fermentation pathway and it may function in } \\
\text { kiwifruit acclimation to waterlogging stress. }\end{array}$ & abscisic acid & [114] \\
\hline Waterlogging & Actinidia deliciosa & $A d R A P 2.3$ & $\begin{array}{l}\text { AdRAP2.3 is an ERF-VII transcription factor and may mediate } \\
\text { waterlogging-resistance by regulating } P D C \text { and } A D H \text { genes. }\end{array}$ & ethylene & [115] \\
\hline Waterlogging & $\begin{array}{c}\text { Chrysanthe-mum } \\
\text { morifolium }\end{array}$ & CmSOS1 & $\begin{array}{l}\text { SOS1 encodes a } \mathrm{Na}^{+} / \mathrm{H}^{+} \text {antiporter and may interact with } \\
\text { CmRCD1 to mediate plant tolerance to waterlogging } \\
\text { stress potentially. }\end{array}$ & & [116] \\
\hline Waterlogging & Cucumber & CsARN6.1 & $\begin{array}{c}\text { CSARN6.1 encodes an AAA ATPase, transgenic lines of CSARN6.1 } \\
\text { increased the number of ARs via enhanced ATPase activity and } \\
\text { further affected waterlogging tolerance. }\end{array}$ & & [117] \\
\hline Waterlogging & Mentha arvensis & $M a R A P 2-4$ & $\begin{array}{l}\text { MaRAP2-4 from Mentha arvensis encodes an ERF-I type } \\
\text { transcription factor, overexpression of MaRAP2-4 in Arabidopsis } \\
\text { enhanced its tolerance to waterlogging and oxidative stress. }\end{array}$ & ethylene, jasmonic acid & [118] \\
\hline Waterlogging & Petunia & PhERF2 & $\begin{array}{l}\text { PhERF2 may regulate the process of programmed cell death and } \\
\text { alcoholic fermentation, on the base of which enhances } \\
\text { waterlogging-tolerance of petunia. }\end{array}$ & ethylene & [119] \\
\hline Submergence & Arabidopsis & WRKY33, WRKY12 & $\begin{array}{c}\text { WRKY33 regulates the expression of RAP2.2 together with } \\
\text { WRKY12, in turn, RAP2.2 exhibits a feedback regulation to } \\
\text { WRKY33. These three genes mediate submergence-tolerance of } \\
\text { Arabidopsis collectively. }\end{array}$ & ethylene & [19] \\
\hline Submergence & Arabidopsis & ANAC017 & $\begin{array}{c}\text { ANAC017 encodes a NAC transcription factor and mediates } \\
\text { differential submergence stress of Arabidopsis in juvenile and } \\
\text { adult stages. }\end{array}$ & & [20] \\
\hline
\end{tabular}




\subsection{The Homeostasis of Reactive Oxygen Species}

Flooding stress leads to oxidative stress for plants, which triggers plant antioxidant systems rapidly [68,77]. Respiratory burst oxidase homolog $(R B O H)$ encodes a plasma membraneassociated NADPH oxidase in plants and can generate hydrogen peroxide $\left(\mathrm{H}_{2} \mathrm{O}_{2}\right)$ by converting $\mathrm{O}_{2}$ to $\mathrm{O}_{2} \cdot{ }^{-}$[127-129]. Qi et al. reported that cucumber accumulated higher levels of ROS under waterlogged stress, further investigation showed that two members CsRBOHB and CsRBOHF3 were strongly upregulated and might result in ROS accumulation [43]. Hypoxia Responsive Universal Stress Protein 1 (HRU1) can be induced by submergence stress in Arabidopsis, and was regulated by an VII Ethylene Response Factor (ERF-VII) protein RAP2.12 (Related to Apetala 2.12) simultaneously; loss of HRU1 function affected $\mathrm{H}_{2} \mathrm{O}_{2}$ production and became sensitive to submergence and anoxia, further research exhibited that HRU1 mediated ROS production in Arabidopsis through an interaction with the GTPase ROP2 and the NADPH oxidase RbohD [130]. The transcriptome of two Brachypodium distachyon ecotypes with contrasting submergence tolerance exhibited that lots of genes associated with redox reaction significantly changed tolerant ecotype, such as genes coding for ascorbate peroxidases (ASP), ascorbate oxidases (ASO) and peroxidases (PER), which might be involved in ROS management under submergence stress [131]. ROS accumulation is harmful for plants, on the other hand, it mediates ARs and aerenchyma formation as signaling molecules. Under flooding stress, how plants keep the balance between oxidative stress and signal transduction needs to be further explored.

\subsection{The Mechanism of Aerenchyma Formation}

Generally, aerenchyma can be classified into two types: schizogenous aerenchyma and lysigenous aerenchyma [132]. Schizogenous aerenchyma that forms gas spaces owing to cell separation and expansion without cell death, by contrast, lysigenous aerenchyma is formed due to the death and subsequent lysis of some cells [53]. Under flooding stress, plants usually form lysigenous aerenchyma in roots to improve oxygen diffusion (e.g., Arabidopsis, maize and wheat) and several genes involved in aerenchyma formation have been investigated $[53,62,90]$ (Figure 2). In Arabidopsis, lysigenous aerenchyma emerged in hypocotyls under hypoxic stress and this process relied on three genes LSD1, EDS1 and PAD4, which regulated the upstream ethylene signal and the generation of ROS [62]. With laser microdissection technology, Rajhi et al. investigated the gene expression profile of cortical cells in maize root when the lysigenous aerenchyma formed, and showed that the expression of $R B O H$ gene increased sharply under waterlogging stress while MT (metallothionein) gene for scavenging ROS was down-regulated, which may lead to the generation of excess ROS and triggered programmed cell death in cortical cells for aerenchyma formation [53]. Additionally, ethylene-induced the formation of aerenchyma under waterlogged conditions [53]. In wheat roots, an ethylene precursor pre-treatment enhanced the expression of three $\mathrm{RBOH}$ genes for ROS generation and activated the formation of lysigenous aerenchyma under stagnant conditions, which might be one of the strategies for wheat seedlings acclimation to hypoxia stress [90]. According to the above researches, it can be concluded that both ethylene and ROS mediate the formation of aerenchyma. Ethylene may induce the generation of ROS and results in the programmed cell death of cortical cells for lysigenous aerenchyma formation eventually.

\subsection{The Forming Basis of ROL Barriers}

Apart from aerenchyma, plants develop ROL barriers in roots to impede oxygen leakage and several genes have been reported to mediate its formation [36] (Figure 2). Previous studies exhibited that suberin might be the major component of ROL barriers compared to lignin. For example, De Simone et al. showed that suberization but not lignification of exodermal cell walls suppressed the radial oxygen loss effectively in roots of four Amazon tree species, indicating it was suberin forming the ROL barriers under flooding stress [133]. Shiono et al. reported that the expression of most genes associated with suberin biosynthesis increased sharply in the outer part of rice roots during ROL 
barrier formation, including GLYCEROL-3-PHOSPHATE ACYLTRANSFERASE (GPAT) and PEROXIDASE (POD), which have also been identified to be upregulated during the formation of ROL barriers with Si supply $[48,134]$, by contrast, few genes related to lignin biosynthesis were found in this process [88]. Additionally, some transcription factors containing WRKY, AP2, MYB, and NAC domains might participate in the regulation of suberin biosynthesis during ROL barrier formation [48,135-137] (Figure 2). Although suberin is considered to be more crucial in forming the ROL barrier of plant roots, the initiation and regulation mechanisms of suberin deposition remain unclear.

\section{Regulatory Mechanisms of Phytohormones in Plants Response to Flooding Stress}

Phytohormones play critical roles in regulating plant growth and can integrate multiple signal transduction pathways under environmental stresses $[138,139]$. Some phytohormones have been identified to be involved in plants adapting to flooding stress, such as ethylene, gibberellin and auxin [13] (Table 3, Figures 2 and 3).

\subsection{Ethylene}

Ethylene is a phytohormone in the form of gas, and hardly escape from plants under flooding conditions, which led to its rapid accumulation inside the plant [13]. The increased ethylene promotes the formation of AR and aerenchyma in plants when exposed to flooding stress $[43,90]$ (Figure 2). ERF-VIIs are ethylene-responsive transcription factors with a conserved APETALA2 (AP2) domain and have been identified to function in plants tolerance to waterlogging and submergence stresses $[17,25,31,104,140]$ (Table 3). Two ERF-VII members SK1 and SK2 from deepwater rice were transcriptionally induced by submergence stress and contributed to the elongation of internodes so as to keep the top leaves from submerging [11,31]. Another ERF-type transcription factor Sub1A, was inducible expression under submergence stress, and overexpression of Sub1A with a tolerance-specific allele in submergence-intolerant variety enhanced its submergence tolerance [104]. ERF-VII member TaERFVII.1 from waterlogging-tolerant wheat (Triticum aestivum) was triggered expression obviously by waterlogging but not in susceptible cultivar, overexpression of TaERFVII.1 increased the waterlogging-tolerance ability of wheat with no adverse effect on its growth and grain production [17], which can be considered as a candidate gene for breeding waterlogging-resistant crops. Yu et al. reported that an ERFVII member from maize, ZmEREB180, was concerned with waterlogging tolerance and its expression level was affected by the changes of $5^{\prime}$-untranslated region (5'-UTR); transgenic maize of ZmEREB180 increased the survival rate through promoting ARs formation and improving antioxidant ability, which was further supported by transcriptomic analysis [25]. As transcription factors, ERF-VIIs usually function by affecting the expression of other genes, however, they are regulated by other transcription factors simultaneously. Recently, Tang et al. reported two transcription factors of WRKY 33 and WRKY12 were involved in Arabidopsis adaptation to submergence stress [19]. WRKY33 interacted with WRKY12 and both of them participated in hypoxia response partially by activating the expression of ERF-VII member RAP2.2 [19]. In addition, overexpression of WRKY33 or WRKY12 in Arabidopsis enhanced resistance to hypoxia [19].

Considering the importance of ERF-VIIs for plant adaption to flooding stress, their members in the model plant Arabidopsis, main crops (rice, maize, wheat and tomato) and other reported ERF-VIIs were collected and constructed a phylogenetic tree. These members can be divided into three groups according to sequence similarity. ERF-VIIs that had been reported to be involved in plant tolerance to flooding stress belongs to Group I and II, no genes associated with flooding-tolerance have yet been found in Group III (Figure 3), which can provide references for screening flooding-tolerant genes more precisely. In brief, ethylene as a major regulator mediated the formation of ARs, aerenchyma, shoot hyponasty and elongation [141]. However, the downstream genes of ethylenesignaling pathway associated with flooding-tolerance are largely unknown. For example, 
ERF-VIIs as transcription factors, usually function by regulating the expression of their target genes, but so far, lots of these upstream genes have not been found and studied.

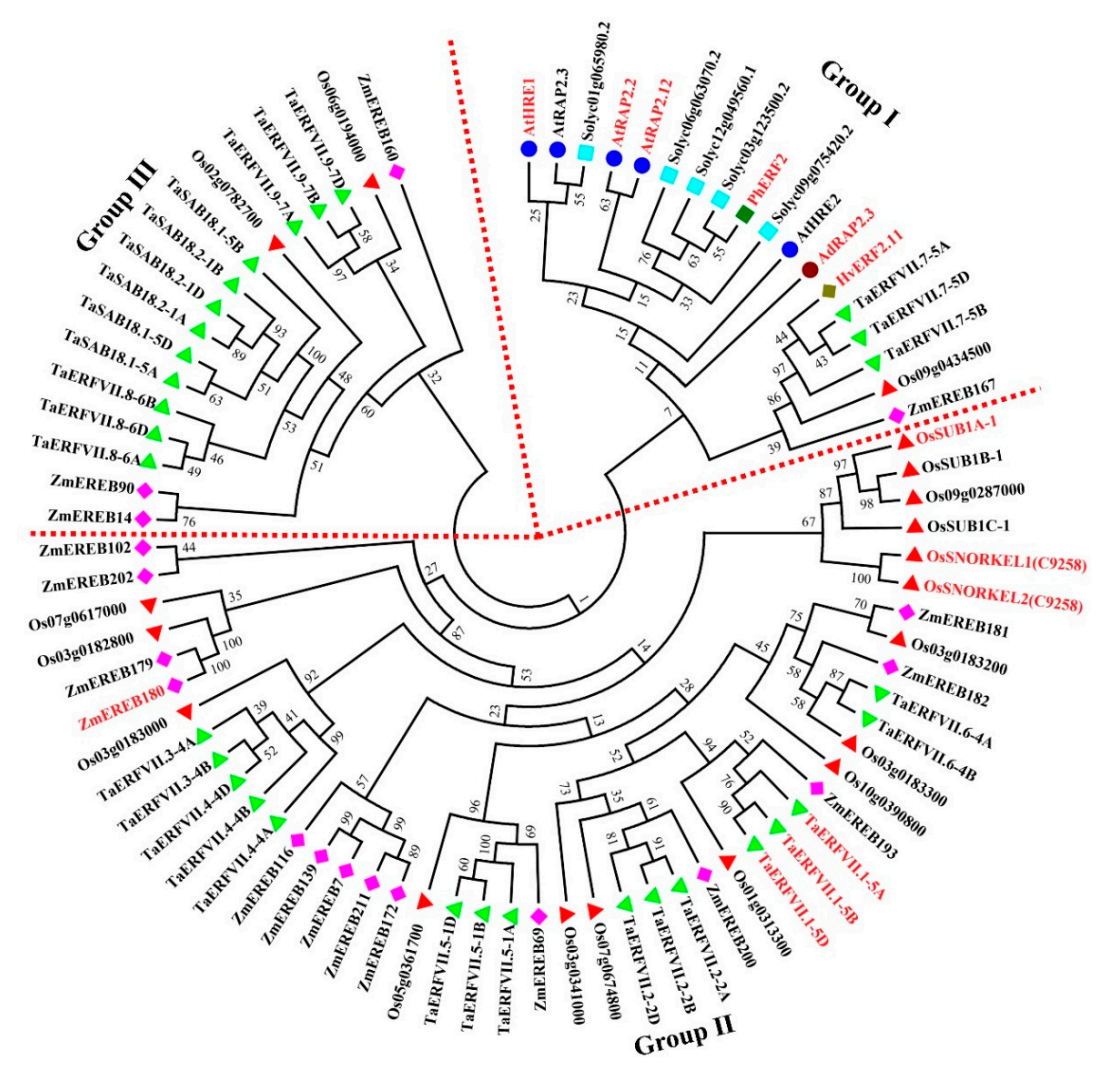

Figure 3. Phylogenetic tree of ERF-VIIs from different plant species. These plant species include model plant Arabidopsis, main crops (rice, maize, wheat, tomato) and other species with ERF-VII members that have been reported. The coding sequences of these ERF-VII genes are listed in Supplemental file 1. The tree was constructed using a neighbor-joining method with 1000 bootstraps in Mega 7 [142]. ERF-VII genes that have been identified to function in flooding-tolerance are marked in red font. Picture shapes with various colors represent ERF-VIIs from different species. $\Delta$, rice; $\square$, tomato; $\bullet$, Arabidopsis; $\diamond$ maize; $\triangle$, wheat; others picture shapes, ERF-VIIs that have been studied.

\subsection{Auxin}

Auxin, which acts as a general coordinator of plant growth and development, has been reported to participate in several plant species adapting to waterlogging stress (Figure 2), such as box elder (Acer negundo) [143], tomato [42], sunflower [144] and cucumber [43]. Auxin functions in the initiation of root apical meristems and increased auxin content may result in the formation of AR primordia $[43,145,146]$. OsPIN1 is a polar auxin transporter from rice and plays an important role in auxin-dependent ARs formation; the loss function of OsPIN1 suppressed the development of ARs apparently and application of auxin partially rescued the missed phenotypes [125]. Another polar auxin transporter PIN2 of Solanum dulcamara could be induced by flooding stress and ethylene application, the silence of PIN2 or impediment of auxin transport with chemical methods inhibited AR primordium initiation [126]. Gutierrez et al. reported that three genes of AUXIN RESPONSE FACTOR (ARF) family regulated ARs initiation cooperatively in Arabidopsis [147]. ARF6 and ARF8 were positive regulators while ARF17 regulated ARs formation negatively. Meanwhile, three auxin-induced Gretchen Hagen3 (GH3) genes (GH3.3, GH3.5, and GH3.6) for the biosynthesis of acyl-acid-amido were necessary for ARs initiation in Arabidopsis hypocotyl [148]. All of these studies indicated that auxin signal participates in plant acclimation to flooding stress mainly through regulating the formation of ARs. 


\subsection{Gibberellin}

Gibberellin was also identified to function in plant adaptation to flooding stress (Figure 4). As suffered from flash floods, submergence-tolerant plants usually restrict their growth by activation of GA signal [149]. Slender Rice-1 (SLR1) and SLR1 Like-1 (SLRL1) are GA signaling repressors in rice [150-152]. Previous research exhibited that Sub1A promoted the accumulation of SLR1 and SLRL1 to suppress GA signal transduction in submergence-tolerant rice under submergence stress, and affected the expression of $P D C$ and $A D H$ genes positively, which led to the inhibited growth of submergence-tolerant rice for energy conservation and regrowth after flooding [104,149,153]. GID1 (GIBBERELLIN INSENSITIVE DWARF1) is a soluble GA receptor and has been reported previously [154]. Under submergence conditions, loss function of GID1 in rice inhibited the degradation of chlorophyll and promoted the metabolism of carbohydrates, further analyses suggested that GID1 regulated GA signals to influence submergence tolerance through controlling carbohydrate consumption [155].

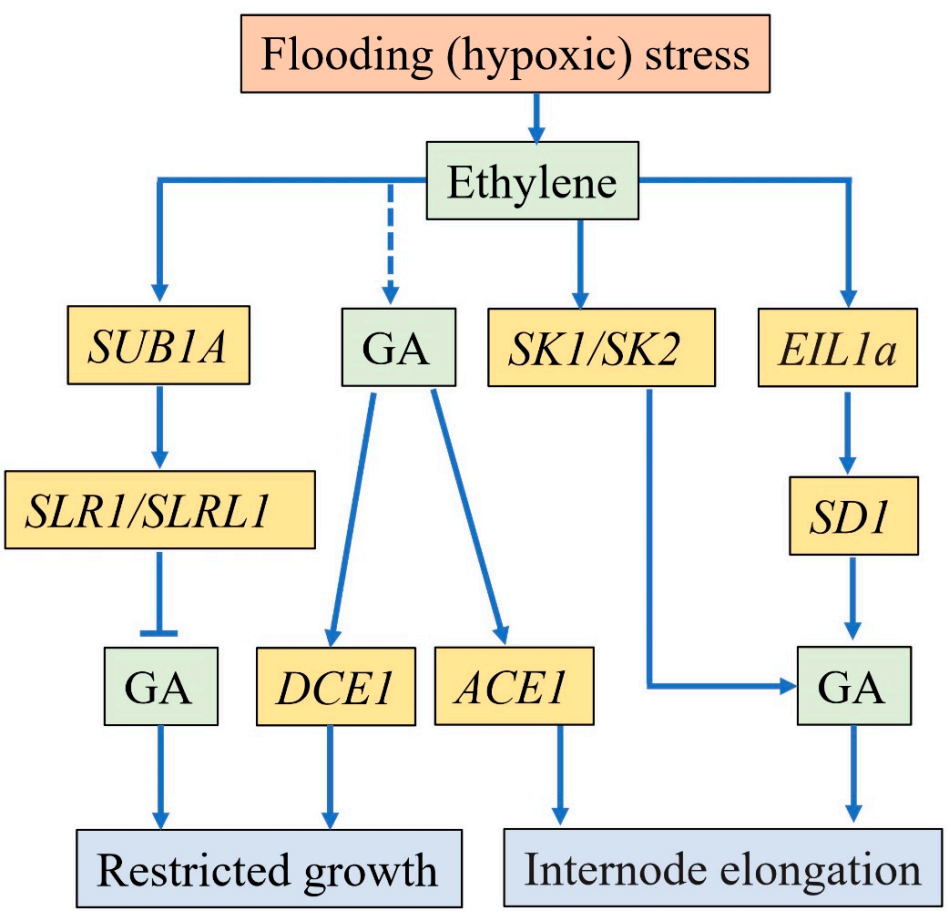

Figure 4. The molecular mechanisms of plants with the 'quiescent' (LOQS) and 'escape' (LOES) strategies as exposed to submergence stress. Generally, flooding stress induces the accumulation of ethylene and then leads to different responses according to flooding depth. Under complete submergence, the ethylene response factor SUB1A is induced and represses the gibberellic acid (GA) signal to prevent shoot elongation through SLR1 and SLRL1 [104,153]. Ethylene accumulation induced by partial-submergence contributes to the expression of the SK1 and SK2, which are involved in the process of internode elongation via GA signal [31]. Ethylene-responsive transcription factor EIL1a can activate the expression of SD1 (a gibberellin biosynthesis gene), then increased the synthesis of gibberellins to promote internode elongation [110]. Additionally, an 'accelerator' ACE1 and a 'decelerator' DEC1 antagonistically regulate internode elongation together with gibberellic acid, expression of ACE1 or downregulation of DEC1 contributes to the internode elongation [18]. The dotted arrow represents that GA may be induced by flooding stress directly without being regulated by ethylene.

GA also plays an important role in the stem elongation of plants [156]. In lowland rice, an increase of active GA (GA1) resulted in the elongation of leaf sheath under submergence stress [157]. For deepwater rice, submergence induced the expression of gibberellin biosynthesis gene SD1 (SEMIDWARF1) that was regulated by an ethylene-responsive transcription 
factor OsEIL1a, and internode elongation was promoted by increasing gibberellins [110]. Recently, two genes, an 'accelerator' $A C E 1$ and a 'decelerator' $D E C 1$, were reported to regulate internode elongation antagonistically together with GA; $A C E 1$, as an unknown function protein, contributed internode elongation in concert with GA while $D E C 1$, as a zinc-finger transcription factor, had the opposite function that restricted internode elongation; these two genes were involved in deepwater rice acclimation to submergence stress collectively [18]. According to the above results, GA mainly functions in plant acclimation to flooding stress through the modulation of carbohydrate metabolism and the regulation of internode (or other organs) elongation. Actually, GA mediates flooding-tolerance of plants together with ethylene in most cases.

\subsection{Other Phytohormones}

Moreover, cytokinin and abscisic acid (ABA) have been identified to function in plants against flooding stress $[114,158,159]$. Waterlogging-induced ARs formation in wheat is relevant to four phytohormones (IAA, GA, cytokinin and ABA) and several genes associated with their biosynthesis or metabolism were inducible expression under waterlogging stress [160]. Salicylic acid (SA) also participates in the waterlogging-tolerance of plants. SA content in waterlogging-tolerant soybean lines increased significantly after waterlogging for 5 or 10 days compared to non-waterlogging conditions while SA content in sensitive lines exhibited no significant change, implying that SA mediates waterlogging-tolerance of soybean through regulating the formation of aerenchyma or ARs [161]. Another phytohormone brassinosteroid (BR) has been reported that it may affect GA signaling by interacting with Sub1A, and regulated the elongation of shoot for surviving under submergence condition [162].

In fact, different phytohormones function cooperatively in response to flooding stress. For instance, the ethylene response factor Sub1A in rice repressed the GA signal to prevent shoot elongation and carbohydrate consumption under complete submergence $[104,149]$. However, when exposed to partial submergence, ethylene accumulation contributed to the expression of SK1 and SK2, which facilitated internode elongation through regulating GA biosynthesis or GA signal transduction [31]. Notably, the expression of SK1 and SK2 may be regulated by one transcription factor EIN3 (ethylene-insensitive-3-like protein) through binding to their promoter regions [31]. To summarize, plant response to flooding stress is a complicated process depending on the co-regulation of multiple phytohormones and the cooperation mechanisms among different hormones need to be further revealed. Meanwhile, the studies about SA and BR regulating flooding-tolerance of plants should be strengthened in the future.

\section{Conclusions and Further Perspectives}

Recently, the mechanisms of plant adaption to flooding stress have been progressively studied. However, there are still several key open questions to be further clarified.

Firstly, since former studies of plants adaption to flooding stress excessively focus on model or wetland plants including Arabidopsis, rice and Rumex, the terrestrial plants should be paid more attention in the future, such as wheat, maize, barely, tomato and soybean. More importantly, it is essential to collect germplasm resources of these terrestrial plants widely owing to phenotypic variation among natural populations, and then the key loci associated with flooding-tolerance can be screened through map-based cloning, genome-wide association study (GWAS) and precision genome editing with the aid of CRISPR-Cas9 system for breeding flooding-resistant varieties.

Secondly, the uptake of multiple mineral nutrients usually becomes disorganized under flooding stress. For example, the concentrations of N, P, K and $\mathrm{Zn}$ in leaves of Lepidium latifolium L. exhibited a decreasing trend as the flooding-time prolongs, and were lower than those in control plants, however, Fe and Mn contents were higher in roots of flooded plants than that in unflooded ones [163]. Mineral elements are crucial for plant growth and the deficiency of mineral nutrients under flooding conditions hastens 
adverse effects on plants. How plants maintain mineral nutrients homeostasis under waterlogging or submergence stress is largely unknown. Additionally, the formation of ROL barriers is one of the typical strategies for plant acclimation to flooding stress, however, its prevention of oxygen loss is nonspecific, and the uptake of water or nutrients is influenced simultaneously $[164,165]$. Thus, the mechanism of plants balancing the impediment of oxygen loss and the uptake of water or nutrients also needs to be further investigated.

Thirdly, flooding stress usually leads to changes in metabolic activities in plants, especially outbreaks of some harmful substances, such as ROS, MDA and acetaldehyde. For instance, flooding-induced oxygen deprivation facilitates the activation of anaerobic respiration and results in the generation of ethanol and acetaldehyde. Ethanol is usually considered to be innocuous for its rapid diffusion from cells while acetaldehyde can poison plant cells [7]. Under the prolonged flooding stress, how does the plant avoid the toxic of acetaldehyde? Whether the flooding-tolerance plants have enhanced capacity or other pathways to scavenge acetaldehyde? These questions remain to be further answered.

Finally, the mechanisms about plants with the 'quiescent strategy' adaption to submergence stress remain to be further investigated, especially the tolerant species that can endure complete submergence stress for a long time. For instance, more than $90 \%$ of bermudagrass can survive after complete submergence for 5 months with water depth up to $25 \mathrm{~m}$ [166]. Under deep submergence, bermudagrass experiences multiple stresses simultaneously, including oxygen deprivation, low temperature, high water pressure and low light or even no light. How does bermudagrass adapt to the stresses over the long term? Exploring the above scientific questions will facilitate understanding the mechanisms of plant acclimation to flooding stress and provide new insights into the breeding of flooding-resistant crops in the future.

Supplementary Materials: Supplementary file 1 can be found at https:/ / www.mdpi.com/1422-006 7/22/3/1088/s1.

Author Contributions: S.W. and W.J. conceived this review, W.J. drafted the manuscript, M.M. and J.C. helped revise and check the manuscript. All authors have read and agreed to the published version of the manuscript.

Funding: The project was financially supported by the Strategic Priority Research Program (A) of the Chinese Academy of Sciences (Grant No. XDA23040303), the Key Program of the Natural Science Foundation of Chongqing (Grant No. cstc2020jcyj-zdxmX0018), the Application of ecological restoration and function enhancement in the water-level-fluctuation zone of Guangyang Island (Grant No. E039620201) and the National Natural Science Foundation of China (Grant No. 42061015).

Institutional Review Board Statement: Not applicable.

Informed Consent Statement: Not applicable.

Conflicts of Interest: Authors declare that they have no conflict of interest.

\section{References}

1. Tanoue, M.; Hirabayashi, Y.; Ikeuchi, H. Global-scale river flood vulnerability in the last 50 years. Sci. Rep. 2016, 6, 36021. [CrossRef] [PubMed]

2. Bailey-Serres, J.; Lee, S.C.; Brinton, E. Waterproofing crops: Effective flooding survival strategies. Plant Physiol. 2012, 160, 1698-1709. [CrossRef] [PubMed]

3. Nishiuchi, S.; Yamauchi, T.; Takahashi, H.; Kotula, L.; Nakazono, M. Mechanisms for coping with submergence and waterlogging in rice. Rice 2012, 5, 2. [CrossRef] [PubMed]

4. Fukao, T.; Barrera-Figueroa, B.E.; Juntawong, P.; Pena-Castro, J.M. Submergence and waterlogging stress in plants: A review highlighting research opportunities and understudied aspects. Front. Plant Sci. 2019, 10, 340. [CrossRef] [PubMed]

5. Catling, D. Rice in Deep Water; Macmillan Press: London, UK, 1992.

6. Setter, T.L.; Waters, I. Review of prospects for germplasm improvement for waterlogging tolerance in wheat, barley and oats. Plant Soil 2013, 253, 1-34. [CrossRef]

7. Bailey-Serres, J.; Voesenek, L.A.C.J. Flooding stress: Acclimations and genetic diversity. Annu. Rev. Plant Biol. 2008, 59, 313-339. [CrossRef]

8. Voesenek, L.A.C.J.; Bailey-Serres, J. Flood adaptive traits and processes: An overview. New Phytol. 2015, 206, 57-73. [CrossRef] 
9. Armstrong, W.; Drew, M.C. Root growth and metabolism under oxygen deficiency. In Plant Roots: The Hidden Half; Waisel, E.A., Kafkafi, Y., Eds.; Marcel Dekker: New York, NY, USA, 2002; pp. 729-761.

10. Colmer, T.D.; Flowers, T.J. Flooding tolerance in halophytes. New Phytol. 2008, 179, 964-974. [CrossRef]

11. Hattori, Y.; Nagai, K.; Ashikari, M. Rice growth adapting to deepwater. Curr. Opin. Plant Biol. 2011, 14, 100-105. [CrossRef]

12. Colmer, T.D.; Voesenek, L.A.C.J. Flooding tolerance: Suites of plant traits in variable environments. Funct. Plant Biol. 2009, 36, 665-681. [CrossRef]

13. Loreti, E.; van Veen, H.; Perata, P. Plant responses to flooding stress. Curr. Opin. Plant Biol. 2016, 33, 64-71. [CrossRef] [PubMed]

14. Visser, E.J.W.; Colmer, T.D.; Blom, C.W.P.M.; Voesenek, L.A.C.J. Changes in growth, porosity, and radial oxygen loss from adventitious roots of selected mono- and dicotyledonous wetland species with contrasting types of aerenchyma. Plant Cell Environ. 2000, 23, 1237-1245. [CrossRef]

15. Colmer, T.D. Aerenchyma and an inducible barrier to radial oxygen loss facilitate root aeration in upland, paddy and deep-water rice (Oryza sativa L.). Ann. Bot. 2003, 91, 301-309. [CrossRef] [PubMed]

16. Jackson, M.B. Ethylene-promoted elongation: An adaptation to submergence stress. Ann. Bot. 2008, 101, 229-248. [CrossRef]

17. Wei, X.N.; Xu, H.J.; Rong, W.; Ye, X.G.; Zhang, Z.Y. Constitutive expression of a stabilized transcription factor group VII ethylene response factor enhances waterlogging tolerance in wheat without penalizing grain yield. Plant Cell Environ. 2019, 42, 1471-1485. [CrossRef]

18. Nagai, K.; Mori, Y.; Ishikawa, S.; Furuta, T.; Gamuyao, R.L.; Niimi, Y.; Hobo, T.; Fukuda, M.; Kojima, M.; Takebayashi, Y.; et al. Antagonistic regulation of the gibberellic acid response during stem growth in rice. Nature 2020, 584, 109-114. [CrossRef]

19. Tang, H.; Bi, H.; Liu, B.; Lou, S.L.; Song, Y.; Tong, S.F.; Chen, N.N.; Jiang, Y.Z.; Liu, J.Q.; Liu, H.H. WRKY33 interacts with WRKY12 protein to up-regulate RAP2.2 during submergence induced hypoxia response in Arabidopsis thaliana. New Phytol. 2021, 229, 106-125. [CrossRef]

20. Bui, L.T.; Shukla, V.; Giorgi, F.M.; Trivellini, A.; Perata, P.; Licausi, F.; Giuntoli, B. Differential submergence tolerance between juvenile and adult Arabidopsis plants involves the ANAC017 transcription factor. Plant J. 2020, 104, 979-994. [CrossRef]

21. Olgun, M.; Metin Kumlay, A.; Cemal Adiguzel, M.; Caglar, A. The effect of waterlogging in wheat (T. aestivum L.). Acta Agric. Scand. Sect. B Soil Plant Sci. 2008, 58, 193-198.

22. Haque, M.E.; Kawaguchi, K.; Komatsu, S. Analysis of proteins in aerenchymatous seminal roots of wheat grown in hypoxic soils under waterlogged conditions. Protein Pept. Lett. 2011, 18, 912-924. [CrossRef]

23. Malik, A.I.; Islam, A.K.M.R.; Colmer, T.D. Transfer of the barrier to radial oxygen loss in roots of Hordeum marinum to wheat (Triticum aestivum): Evaluation of four H. marinum-wheat amphiploids. New Phytol. 2011, 190, 499-508. [CrossRef] [PubMed]

24. Panozzo, A.; Dal Cortivo, C.; Ferrari, M.; Vicelli, B.; Varotto, S.; Vamerali, T. Morphological changes and expressions of $A O X 1 A$, CYP81D8, and putative PFP genes in a large set of commercial maize hybrids under extreme waterlogging. Front. Plant Sci. 2019, 10, 62. [CrossRef] [PubMed]

25. Yu, F.; Liang, K.; Fang, T.; Zhao, H.L.; Han, X.S.; Cai, M.J.; Qiu, F.Z. A group VII ethylene response factor gene, ZmEREB180, coordinates waterlogging tolerance in maize seedlings. Plant Biotechnol. J. 2019, 17, 2286-2298. [CrossRef] [PubMed]

26. Ren, B.Z.; Zhang, J.W.; Li, X.; Fan, X.; Dong, S.T.; Liu, P.; Zhao, B. Effects of waterlogging on the yield and growth of summer maize under field conditions. Can. J. Plant Sci. 2014, 94, 23-31. [CrossRef]

27. Baranwal, S.; Singh, B.B. Effect of waterlogging on growth, chlorophylls and saccharides content in maize genotypes. Indian J. Plant Physiol. 2002, 7, 246-251.

28. Jackson, M.B.; Ram, P.C. Physiological and molecular basis of susceptibility and tolerance of rice plants to complete submergence. Ann. Bot. 2003, 91, 227-241. [CrossRef]

29. Bailey-Serres, J.; Fukao, T.; Ronald, P.; Ismail, A.; Heuer, S.; Mackill, D. Submergence tolerant rice: SUB1's journey from landrace to modern cultivar. Rice 2010, 3, 138-147. [CrossRef]

30. Kende, H.; van der Knaap, E.; Cho, H.T. Deepwater rice: A model plant to study stem elongation. Plant Physiol. 1998, 118, 1105-1110. [CrossRef]

31. Hattori, Y.; Nagai, K.; Furukawa, S.; Song, X.J.; Kawano, R.; Sakakibara, H.; Wu, J.Z.; Matsumoto, T.; Yoshimura, A.; Kitano, H.; et al. The ethylene response factors SNORKEL1 and SNORKEL2 allow rice to adapt to deep water. Nature 2009, 460, 1026-1030. [CrossRef]

32. Githiri, S.M.; Watanabe, S.; Harada, K.; Takahashi, R. QTL analysis of flooding tolerance in soybean at an early vegetative growth stage. Plant Breed. 2006, 125, 613-618. [CrossRef]

33. Tamang, B.G.; Magliozzi, J.O.; Maroof, M.A.; Fukao, T. Physiological and transcriptomic characterization of submergence and reoxygenation responses in soybean seedlings. Plant Cell Environ. 2014, 37, 2350-2365. [CrossRef]

34. Wang, X.; Sakata, K.; Komatsu, S. An integrated approach of proteomics and computational genetic modification effectiveness analysis to uncover the mechanism of flood tolerance in soybeans. Int. J. Mol. Sci. 2018, 19, 1301. [CrossRef] [PubMed]

35. Garcia, N.; da-Silva, C.J.; Cocco, K.L.T.; Pomagualli, D.; de Oliveira, F.K.; da Silva, J.V.L.; de Oliveira, A.C.B.; do Amarante, L. Waterlogging tolerance of five soybean genotypes through different physiological and biochemical mechanisms. Environ. Exp. Bot. 2020, 172, 103975. [CrossRef]

36. Striker, G.G. Flooding stress on plants: Anatomical, morphological and physiological responses. In Botany; Mworia, J.K., Ed.; InTech: Rijeka, Croatia, 2012.

37. Steffens, B.; Rasmussen, A. The physiology of adventitious roots. Plant Physiol. 2016, 170, 603-617. [CrossRef] [PubMed]

38. Zhai, L.H.; Liu, Z.J.; Zou, X.L.; Jiang, Y.Y.; Qiu, F.Z.; Zheng, Y.L.; Zhang, Z.X. Genome-wide identification and analysis of microRNA responding to long-term waterlogging in crown roots of maize seedlings. Physiol. Plant 2013, 147, 181-193. [CrossRef] 
39. Lorbiecke, R.; Sauter, M. Adventitious root growth and cell-cycle induction in deepwater rice. Plant Physiol. 1999, 119, 21-30. [CrossRef]

40. Mergemann, H.; Sauter, M. Ethylene induces epidermal cell death at the site of adventitious root emergence in rice. Plant Physiol. 2000, 124, 609-614. [CrossRef]

41. Else, M.A.; Janowiak, F.; Atkinson, C.J.; Jackson, M.B. Root signals and stomatal closure in relation to photosynthesis, chlorophyll a fluorescence and adventitious rooting of flooded tomato plants. Ann. Bot. 2009, 103, 313-323. [CrossRef]

42. Vidoz, M.L.; Loreti, E.; Mensuali, A.; Alpi, A.; Perata, P. Hormonal interplay during adventitious root formation in flooded tomato plants. Plant J. 2010, 63, 551-562. [CrossRef]

43. Qi, X.H.; Li, Q.Q.; Ma, X.T.; Qian, C.L.; Wang, H.H.; Ren, N.N.; Shen, C.X.; Huang, S.M.; Xu, X.W.; Xu, Q.; et al. Waterlogginginduced adventitious root formation in cucumber is regulated by ethylene and auxin through reactive oxygen species signalling. Plant Cell Environ. 2019, 42, 1458-1470. [CrossRef]

44. Visser, E.J.W.; Cohen, J.D.; Barendse, G.W.M.; Blom, C.W.P.M.; Voesenek, L.A.C.J. An ethylene-mediated increase in sensitivity to auxin induces adventitious root formation in flooded Rumex palustris Sm. Plant Physiol. 1996, 112, 1687-1692. [CrossRef] [PubMed]

45. Colmer, T.D.; Gibberd, M.R.; Wiengweera, A.; Tinh, T.K. The barrier to radial oxygen loss from roots of rice (Oryza sativa L.) is induced by growth in stagnant solution. J. Exp. Bot. 1998, 49, 1431-1436. [CrossRef]

46. Kotula, L.; Ranathunge, K.; Schreiber, L.; Steudle, E. Functional and chemical comparison of apoplastic barriers to radial oxygen loss in roots of rice (Oryza sativa L.) grown in aerated or deoxygenated solution. J. Exp. Bot. 2009, 60, 2155-2167. [CrossRef] [PubMed]

47. Steffens, B.; Geske, T.; Sauter, M. Aerenchyma formation in the rice stem and its promotion by $\mathrm{H}_{2} \mathrm{O}_{2}$. New Phytol. 2011, 190, 369-378. [CrossRef] [PubMed]

48. Shiono, K.; Yamauchi, T.; Yamazaki, S.; Mohanty, B.; Malik, A.I.; Nagamura, Y.; Nishizawa, N.K.; Tsutsumi, N.; Colmer, T.D.; Nakazono, M. Microarray analysis of laser-microdissected tissues indicates the biosynthesis of suberin in the outer part of roots during formation of a barrier to radial oxygen loss in rice (Oryza sativa). J. Exp. Bot. 2014, 65, 4795-4806. [CrossRef]

49. Abiko, T.; Kotula, L.; Shiono, K.; Malik, A.I.; Colmer, T.D.; Nakazono, M. Enhanced formation of aerenchyma and induction of a barrier to radial oxygen loss in adventitious roots of Zea nicaraguensis contribute to its waterlogging tolerance as compared with maize (Zea mays ssp mays). Plant Cell Environ. 2012, 35, 1618-1630. [CrossRef]

50. Mano, Y.; Omori, F. Relationship between constitutive root aerenchyma formation and flooding tolerance in Zea nicaraguensis. Plant Soil 2013, 370, 447-460. [CrossRef]

51. Watanabe, K.; Takahashi, H.; Sato, S.; Nishiuchi, S.; Omori, F.; Malik, A.I.; Colmer, T.D.; Mano, Y.; Nakazono, M. A major locus involved in the formation of the radial oxygen loss barrier in adventitious roots of teosinte Zea nicaraguensis is located on the short-arm of chromosome 3. Plant Cell Environ. 2017, 40, 304-316. [CrossRef]

52. Mano, Y.; Omori, F.; Takamizo, T.; Kindiger, B.; Bird, R.M.; Loaisiga, C.H. Variation for root aerenchyma formation in flooded and non-flooded maize and teosinte seedlings. Plant Soil 2006, 281, 269-279. [CrossRef]

53. Rajhi, I.; Yamauchi, T.; Takahashi, H.; Nishiuchi, S.; Shiono, K.; Watanabe, R.; Mliki, A.; Nagamura, Y.; Tsutsumi, N.; Nishizawa, N.K.; et al. Identification of genes expressed in maize root cortical cells during lysigenous aerenchyma formation using laser microdissection and microarray analyses. New Phytol. 2011, 190, 351-368. [CrossRef]

54. Huang, B.R.; Johnson, J.W.; Nesmith, S.; Bridges, D.C. Growth, physiological and anatomical responses of 2 wheat genotypes to waterlogging and nutrient supply. J. Exp. Bot. 1994, 45, 193-202. [CrossRef]

55. Jiang, Z.; Song, X.F.; Zhou, Z.Q.; Wang, L.K.; Li, J.W.; Deng, X.Y.; Fan, H.Y. Aerenchyma formation: Programmed cell death in adventitious roots of winter wheat (Triticum aestivum) under waterlogging. Funct. Plant Biol. 2010, 37, 748-755. [CrossRef]

56. Xu, Q.T.; Yang, L.; Zhou, Z.Q.; Mei, F.Z.; Qu, L.H.; Zhou, G.S. Process of aerenchyma formation and reactive oxygen species induced by waterlogging in wheat seminal roots. Planta 2013, 238, 969-982. [CrossRef] [PubMed]

57. Zhang, X.C.; Shabala, S.; Koutoulis, A.; Shabala, L.; Johnson, P.; Hayes, D.; Nichols, D.S.; Zhou, M.X. Waterlogging tolerance in barley is associated with faster aerenchyma formation in adventitious roots. Plant Soil 2015, 394, 355-372. [CrossRef]

58. Laan, P.; Berrevoets, M.J.; Lythe, S.; Armstrong, W.; Blom, C.W.P.M. Root morphology and aerenchyma formation as indicators of the flood-tolerance of Rumex species. J. Ecol. 1989, 77, 693-703. [CrossRef]

59. Visser, E.J.W.; Heijink, C.J.; Vanhout, K.J.G.M.; Voesenek, L.A.C.J.; Barendse, G.W.M.; Blom, C.W.P.M. Regulatory role of auxin in adventitious root-formation in two Species of Rumex, differing in their sensitivity to waterlogging. Physiol. Plant. 1995, 93, 116-122. [CrossRef]

60. Wample, R.L.; Reid, D.M. Control of adventitious root production and hypocotyl hypertrophy of sunflower (Helianthus Annuus) in response to flooding. Physiol. Plant. 1978, 44, 351-358. [CrossRef]

61. Jackson, M.B.; Attwood, P.A. Roots of willow (Salix viminalis L) show marked tolerance to oxygen shortage in flooded soils and in solution culture. Plant Soil 1996, 187, 37-45. [CrossRef]

62. Mühlenbock, P.; Plaszczyca, M.; Plaszczyca, M.; Mellerowicz, E.; Karpinski, S. Lysigenous aerenchyma formation in Arabidopsis is controlled by LESION SIMULATING DISEASE1. Plant Cell 2007, 19, 3819-3830. [CrossRef]

63. Dawood, T.; Rieu, I.; Wolters-Arts, M.; Derksen, E.B.; Mariani, C.; Visser, E.J.W. Rapid flooding-induced adventitious root development from preformed primordia in Solanum dulcamara. AoB Plants 2014, 6. [CrossRef]

64. Hua, J.F.; Han, L.W.; Wang, Z.Q.; Gu, C.S.; Yin, Y.L. Morpho-anatomical and photosynthetic responses of Taxodium hybrid 'Zhongshanshan' 406 to prolonged flooding. Flora 2017, 231, 29-37. [CrossRef]

65. Xiao, B.; Jespersen, D. Morphological and physiological responses of seashore paspalum and bermudagrass to waterlogging stress. J. Am. Soc. Hortic. Sci. 2019, 144, 305-313. [CrossRef] 
66. Ejiri, M.; Shiono, K. Prevention of radial oxygen loss is associated with exodermal suberin along adventitious roots of annual wild species of Echinochloa. Front. Plant Sci. 2019, 10, 254. [CrossRef] [PubMed]

67. Jia, L.T.; Qin, X.; Lyu, D.G.; Qin, S.J.; Zhang, P. ROS production and scavenging in three cherry rootstocks under short-term waterlogging conditions. Sci. Hortic. 2019, 257, 108647. [CrossRef]

68. Ye, T.T.; Shi, H.T.; Wang, Y.P.; Chan, Z.L. Contrasting changes caused by drought and submergence stresses in bermudagrass (Cynodon dactylon). Front. Plant Sci. 2015, 6, 951. [CrossRef]

69. Wang, J.; Sun, H.; Sheng, J.J.; Jin, S.R.; Zhou, F.S.; Hu, Z.L.; Diao, Y. Transcriptome, physiological and biochemical analysis of Triarrhena sacchariflora in response to flooding stress. BMC Genet. 2019, 20, 88. [CrossRef]

70. Mittler, R. Oxidative stress, antioxidants and stress tolerance. Trends Plant Sci. 2002, 7, 405-410. [CrossRef]

71. Choudhury, F.K.; Rivero, R.M.; Blumwald, E.; Mittler, R. Reactive oxygen species, abiotic stress and stress combination. Plant J. 2017, 90, 856-867. [CrossRef]

72. Gill, M.B.; Zeng, F.R.; Shabala, L.; Zhang, G.P.; Yu, M.; Demidchik, V.; Shabala, S.; Zhou, M.X. Identification of QTL related to ROS formation under hypoxia and their association with waterlogging and salt tolerance in barley. Int. J. Mol. Sci. 2019, 20, 699. [CrossRef]

73. Yordanova, R.Y.; Christov, K.N.; Popova, L.P. Antioxidative enzymes in barley plants subjected to soil flooding. Environ. Exp. Bot. 2004, 51, 93-101. [CrossRef]

74. Damanik, R.I.; Maziah, M.; Ismail, M.R.; Ahmad, S.; Zain, A. Responses of the antioxidative enzymes in Malaysian rice (Oryza sativa L.) cultivars under submergence condition. Acta Physiol. Plant. 2010, 32, 739-747. [CrossRef]

75. Tan, W.; Liu, J.; Dai, T.; Jing, Q.; Cao, W.; Jiang, D. Alterations in photosynthesis and antioxidant enzyme activity in winter wheat subjected to post-anthesis waterlogging. Photosynthetica 2008, 46, 21-27. [CrossRef]

76. Tang, B.; Xu, S.Z.; Zou, X.L.; Zheng, Y.L.; Qiu, F.Z. Changes of antioxidative enzymes and lipid peroxidation in leaves and roots of waterlogging-tolerant and waterlogging-sensitive maize genotypes at seedling stage. Agr. Sci. China 2010, 9, 651-661. [CrossRef]

77. Arbona, V.; Hossain, Z.; Lopez-Climent, M.F.; Perez-Clemente, R.M.; Gomez-Cadenas, A. Antioxidant enzymatic activity is linked to waterlogging stress tolerance in citrus. Physiol. Plantarum 2008, 132, 452-466. [CrossRef] [PubMed]

78. Hossain, Z.; Lopez-Climent, M.F.; Arbona, V.; Perez-Clemente, R.M.; Gomez-Cadenas, A. Modulation of the antioxidant system in citrus under waterlogging and subsequent drainage. J. Plant Physiol. 2009, 166, 1391-1404. [CrossRef]

79. Yu, Q.; Rengel, Z. Waterlogging influences plant growth and activities of superoxide dismutases in narrow-leafed lupin and transgenic tobacco plants. J. Plant Physiol. 1999, 155, 431-438. [CrossRef]

80. Ushimaru, T.; Kanematsu, S.; Katayama, M.; Tsuji, H. Antioxidative enzymes in seedlings of Nelumbo nucifera germinated under water. Physiol. Plant. 2001, 112, 39-46. [CrossRef]

81. Wang, K.H.; Jiang, Y.W. Antioxidant responses of creeping bentgrass roots to waterlogging. Crop Sci. 2007, 47, 232-238. [CrossRef]

82. Kumutha, D.; Ezhilmathi, K.; Sairam, R.K.; Srivastava, G.C.; Deshmukh, P.S.; Meena, R.C. Waterlogging induced oxidative stress and antioxidant activity in pigeonpea genotypes. Biol. Plant. 2009, 53, 75-84. [CrossRef]

83. Sairam, R.K.; Kumutha, D.; Ezhilmathi, K.; Chinnusamy, V.; Meena, R.C. Waterlogging induced oxidative stress and antioxidant enzyme activities in pigeon pea. Biol. Plant. 2009, 53, 493-504. [CrossRef]

84. Liu, M.X.; Jiang, Y.W. Genotypic variation in growth and metabolic responses of perennial ryegrass exposed to short-term waterlogging and submergence stress. Plant Physiol. Biochem. 2015, 95, 57-64. [CrossRef] [PubMed]

85. Voesenek, L.A.C.J.; Bailey-Serres, J. Flooding tolerance: $\mathrm{O}_{2}$ sensing and survival strategies. Curr. Opin. Plant Biol. 2013, 16, 647-653. [CrossRef] [PubMed]

86. Vervuren, P.J.A.; Blom, C.W.P.M.; de Kroon, H. Extreme flooding events on the Rhine and the survival and distribution of riparian plant species. J. Ecol. 2003, 91, 135-146. [CrossRef]

87. Loreti, E.; Valeri, M.C.; Novi, G.; Perata, P. Gene regulation and survival under hypoxia requires starch availability and metabolism. Plant Physiol. 2018, 176, 1286-1298. [CrossRef]

88. Tian, L.X.; Li, J.; Bi, W.S.; Zuo, S.Y.; Li, L.J.; Li, W.L.; Sun, L. Effects of waterlogging stress at different growth stages on the photosynthetic characteristics and grain yield of spring maize (Zea mays L.) under field conditions. Agric. Water Manag. 2019, 218, 250-258. [CrossRef]

89. Evans, D.E. Aerenchyma formation. New Phytol. 2003, 161, 35-49. [CrossRef]

90. Yamauchi, T.; Watanabe, K.; Fukazawa, A.; Mori, H.; Abe, F.; Kawaguchi, K.; Oyanagi, A.; Nakazono, M. Ethylene and reactive oxygen species are involved in root aerenchyma formation and adaptation of wheat seedlings to oxygen-deficient conditions. $J$. Exp. Bot. 2014, 65, 261-273. [CrossRef]

91. McDonald, M.P.; Galwey, N.W.; Colmer, T.D. Similarity and diversity in adventitious root anatomy as related to root aeration among a range of wetland and dryland grass species. Plant Cell Environ. 2002, 25, 441-451. [CrossRef]

92. Soukup, A.; Armstrong, W.; Schreiber, L.; Franke, R.; Votrubova, O. Apoplastic barriers to radial oxygen loss and solute penetration: A chemical and functional comparison of the exodermis of two wetland species, Phragmites australis and Glyceria maxima. New Phytol. 2007, 173, 264-278. [CrossRef]

93. Shiono, K.; Ogawa, S.; Yamazaki, S.; Isoda, H.; Fujimura, T.; Nakazono, M.; Colmer, T.D. Contrasting dynamics of radial $\mathrm{O}_{2}$-loss barrier induction and aerenchyma formation in rice roots of two lengths. Ann. Bot. 2011, 107, 89-99. [CrossRef]

94. Kotula, L.; Colmer, T.D.; Nakazono, M. Effects of organic acids on the formation of the barrier to radial oxygen loss in roots of Hordeum marinum. Funct. Plant Biol. 2014, 41, 187-202. [CrossRef] [PubMed] 
95. Colmer, T.D.; Kotula, L.; Malik, A.; Takahashi, H.; Konnerup, D.; Nakazono, M. Rice acclimation to soil flooding: Low concentrations of organic acids can trigger a barrier to radial oxygen loss in roots. Plant Cell Environ. 2019, 42, $2183-2197$. [CrossRef] [PubMed]

96. Rao, D.N.; Mikkelsen, D.S. Effects of acetic, propionic, and butyric acids on rice seedling growth and nutrition. Plant Soil 1977, 47, 323-334. [CrossRef]

97. Armstrong, J.; Armstrong, W. Rice and Phragmites: Effects of organic acids on growth, root permeability, and radial oxygen loss to the rhizosphere. Am. J. Bot. 2001, 88, 1359-1370. [CrossRef]

98. Dolferus, R.; Wolansky, M.; Carroll, R.; Miyashita, Y.; Ismond, K.; Good, A. Functional analysis of lactate dehydrogenase during hypoxic stress in Arabidopsis. Funct. Plant Biol. 2008, 35, 131-140. [CrossRef] [PubMed]

99. Hinz, M.; Wilson, I.W.; Yang, J.; Buerstenbinder, K.; Llewellyn, D.J.; Dennis, E.S.; Sauter, M.; Dolferus, R. Arabidopsis RAP2.2: An ethylene response transcription factor that is important for hypoxia survival. Plant Physiol. 2010, 153, 757-772. [CrossRef]

100. Licausi, F.; Van Dongen, J.T.; Giuntoli, B.; Novi, G.; Santaniello, A.; Geigenberger, P.; Perata, P. HRE1 and HRE2, two hypoxiainducible ethylene response factors, affect anaerobic responses in Arabidopsis thaliana. Plant J. 2010, 62, 302-315. [CrossRef]

101. Licausi, F.; Kosmacz, M.; Weits, D.A.; Giuntoli, B.; Giorgi, F.M.; Voesenek, L.A.C.J.; Perata, P.; Van Dongen, J.T. Oxygen sensing in plants is mediated by an N-end rule pathway for protein destabilization. Nature 2011, 479, 419-422. [CrossRef]

102. Weits, D.A.; Giuntoli, B.; Kosmacz, M.; Parlanti, S.; Hubberten, H.M.; Riegler, H. Plant cysteine oxidases control the oxygendependent branch of the N-end-rule pathway. Nat. Commun. 2014, 5, 3425. [CrossRef]

103. Lin, I.S.; Wu, Y.S.; Chen, C.T.; Chen, G.H.; Hwang, S.G.; Jauh, G.Y.; Tzen, J.T.; Yang, C.Y. AtRBOH I confers submergence tolerance and is involved in auxin-mediated signaling pathways under hypoxic stress. Plant Growth Regul. 2017, 83, 277-285. [CrossRef]

104. Xu, K.N.; Xu, X.; Fukao, T.; Canlas, P.; Maghirang-Rodriguez, R.; Heuer, S.; Ismail, A.M.; Bailey-Serres, J.; Ronald, P.C.; Mackill, D.J. Sub1A is an ethylene-response-factor-like gene that confers submergence tolerance to rice. Nature 2006, 442, 705-708. [CrossRef] [PubMed]

105. Lee, K.W.; Chen, P.W.; Lu, C.A.; Chen, S.; Ho, T.H.D.; Yu, S.M. Coordinated responses to oxygen and sugar deficiency allow rice seedlings to tolerate flooding. Sci. Signal. 2009, 2, ra61. [CrossRef] [PubMed]

106. Minji, P.; Huikyeong, Y.; Hyeokgon, P.; Jun, L.; Soohwan, K.; Yongsic, H. Interference with oxidative phosphorylation enhances anoxic expression of rice $\alpha$-amylase genes through abolishing sugar regulation. J. Exp. Bot. 2010, 61, 3235-3244.

107. Kretzschmar, T.; Pelayo, M.A.; Trijatmiko, K.R.; Gabunada, L.F.; Alam, R.; Jimenez, R.; Mendioro, M.S.; Slamet-Loedin, I.H.; Sreenivasulu, N.; Bailey-Serres, J.; et al. A trehalose-6-phosphate phosphatase enhances anaerobic germination tolerance in rice. Nat. Plants 2015, 1, 15124. [CrossRef] [PubMed]

108. Jisha, V.; Dampanaboina, L.; Vadassery, J.; Mithöfer, A.; Kappara, S.; Ramanan, R. Overexpression of an AP2/ERF type transcription factor OsEREBP1 confers biotic and abiotic stress tolerance in rice. PLoS ONE 2015, 10, e0127831. [CrossRef]

109. Kurokawa, Y.; Nagai, K.; Huan, P.D.; Shimazaki, K.; Qu, H.Q.; Mori, Y.; Toda, Y.; Kuroha, T.; Hayashi, N.; Aiga, S.; et al. Rice leaf hydrophobicity and gas films are conferred by a wax synthesis gene (LGF1) and contribute to flood tolerance. New Phytol. 2018, 218, 1558-1569. [CrossRef]

110. Kuroha, T.; Nagai, K.; Gamuyao, R.; Wang, D.R.; Furuta, T.; Nakamori, M.; Kitaoka, T.; Adachi, K.; Minami, A.; Mori, Y.; et al. Ethylene-gibberellin signaling underlies adaptation of rice to periodic flooding. Science 2018, 361, 181-185. [CrossRef]

111. Liang, S.; Xiong, W.; Yin, C.; Xie, X.; Jin, Y.J.; Zhang, S.; Yang, B.; Ye, G.Y.; Chen, S.Y.; Luan, W.J. Overexpression of OsARD1 improves submergence, drought, and salt tolerances of seedling through the enhancement of ethylene synthesis in rice. Front. Plant Sci. 2019, 10, 1088. [CrossRef]

112. Campbell, M.T.; Proctor, C.A.; Dou, Y.C.; Schmitz, A.J.; Phansak, P.; Kruger, G.R.; Zhang, C.; Walia, H. Genetic and molecular characterization of submergence response identifies Subtol6 as a major submergence tolerance locus in maize. PLoS ONE 2015, 10, e0120385. [CrossRef]

113. Luan, H.Y.; Guo, B.J.; Shen, H.Q.; Pan, Y.H.; Hong, Y.; Lv, C.; Xu, R.G. Overexpression of barley transcription factor HvERF2.11 in Arabidopsis enhances plant waterlogging tolerance. Int. J. Mol. Sci. 2020, 21, 1982. [CrossRef]

114. Zhang, J.Y.; Huang, S.N.; Wang, G.; Xuan, J.P.; Guo, Z.R. Overexpression of Actinidia deliciosa pyruvate decarboxylase 1 gene enhances waterlogging stress in transgenic Arabidopsis thaliana. Plant Physiol. Biochem. 2016, 106, 244-252. [CrossRef] [PubMed]

115. Pan, D.L.; Wang, G.; Wang, T.; Jia, Z.H.; Guo, Z.R.; Zhang, J.Y. AdRAP2.3, a novel ethylene response factor VII from Actinidia deliciosa, enhances waterlogging resistance in transgenic tobacco through improving expression levels of PDC and ADH genes. Int. J. Mol. Sci. 2019, 20, 1189. [CrossRef] [PubMed]

116. Wang, L.J.; Gao, J.J.; Zhang, Z.X.; Liu, W.M.; Cheng, P.L.; Mu, W.T.; Su, T.; Chen, S.M.; Chen, F.D.; Jiang, J.F. Overexpression of CmSOS1 confers waterlogging tolerance in Chrysanthemum. J. Integr. Plant Biol. 2020, 62, 1059-1064. [CrossRef] [PubMed]

117. Xu, X.W.; Ji, J.; Xu, Q.; Qi, X.H.; Weng, Y.Q.; Chen, X.H. The major-effect quantitative trait locus CsARN6.1 encodes an AAA ATPase domain-containing protein that is associated with waterlogging stress tolerance by promoting adventitious root formation. Plant J. 2018, 93, 917-930. [CrossRef] [PubMed]

118. Phukan, U.J.; Jeena, G.S.; Tripathi, V.; Shukla, R.K. MaRAP2-4, a waterlogging-responsive ERF from Mentha, regulates bidirectional sugar transporter AtSWEET10 to modulate stress response in Arabidopsis. Plant Biotechnol. J. 2018, 16, 221-233. [CrossRef]

119. Yin, D.M.; Sun, D.Y.; Han, Z.Q.; Ni, D.; Norris, A.; Jiang, C.Z. PhERF2, an ethylene-responsive element binding factor, plays an essential role in waterlogging tolerance of petunia. Hortic. Res. 2019, 6, 83. [CrossRef]

120. Liu, S.; Wang, J.; Wang, L.; Wang, X.; Xue, Y.; Wu, P.; Shou, H.X. Adventitious root formation in rice requires OsGNOM1 and is mediated by the OsPINs family. Cell Res. 2009, 19, 1110-1119. [CrossRef] 
121. Steinmann, T.; Geldner, N.; Grebe, M.; Mangold, S.; Jackson, C.L.; Paris, S.; Gälweiler, L.; Palme, K.; Jürgens, G. Coordinated polar localization of auxin efflux carrier PIN1 by GNOM ARF GEF. Science 1999, 286, 316-318. [CrossRef]

122. Geldner, N.; Anders, N.; Wolters, H.; Keicher, J.; Kornberger, W.; Muller, P.; Delbarre, A.; Ueda, T.; Nakano, A.; Jürgens, G. The Arabidopsis GNOM ARF-GEF mediates endosomal recycling, auxin transport, and auxin-dependent plant growth. Cell 2003, 112, 219-230. [CrossRef]

123. Steffens, B.; Sauter, M. Epidermal cell death in rice is confined to cells with a distinct molecular identity and is mediated by ethylene and $\mathrm{H}_{2} \mathrm{O}_{2}$ through an autoamplified signal pathway. Plant Cell 2009, 21, 184-196. [CrossRef]

124. Steffens, B.; Kovalev, A.; Gorb, S.N.; Sauter, M. Emerging roots alter epidermal cell fate through mechanical and reactive oxygen species signaling. Plant Cell 2012, 24, 3296-3306. [CrossRef] [PubMed]

125. Xu, M.; Zhu, L.; Shou, H.; Wu, P. A PIN1 family gene, OsPIN1, involved in auxin-dependent adventitious root emergence and tillering in rice. Plant Cell Physiol. 2005, 46, 1674-1681. [CrossRef] [PubMed]

126. Dawood, T.; Yang, X.; Visser, E.J.; Te Beek, T.A.; Kensche, P.R.; Cristescu, S.M.; Lee, S.; Floková, K.; Nguyen, D.; Mariani, C.; et al. A co-opted hormonal cascade activates dormant adventitious root primordia upon flooding in Solanum dulcamara. Plant Physiol. 2016, 170, 2351-2364. [CrossRef] [PubMed]

127. Overmyer, K.; Brosche, M.; Kangasjarvi, J. Reactive oxygen species and hormonal control of cell death. Trends Plant Sci. 2003, 8, 335-342. [CrossRef]

128. Torres, M.A.; Dangl, J.L. Functions of the respiratory burst oxidase in biotic interactions, abiotic stress and development. Curr. Opin. Plant Biol. 2005, 8, 397-403. [CrossRef] [PubMed]

129. Yamauchi, T.; Rajhi, I.; Nakazono, M. Lysigenous aerenchyma formation in maize root is confined to cortical cells by regulation of genes related to generation and scavenging of reactive oxygen species. Plant Signal. Behav. 2011, 6, 759-761. [CrossRef]

130. Gonzali, S.; Loreti, E.; Cardarelli, F.; Novi, G.; Parlanti, S.; Pucciariello, C.; Bassolino, L.; Banti, V.; Licausi, F.; Perata, P. Universal stress protein HRU1 mediates ROS homeostasis under anoxia. Nat. Plants 2015, 1, 15151. [CrossRef]

131. Rivera-Contreras, I.K.; Zamora-Hernandez, T.; Huerta-Heredia, A.A.; Capataz-Tafur, J.; Barrera-Figueroa, B.E.; Juntawong, P.; Peña-Castro, J.M. Transcriptomic analysis of submergence-tolerant and sensitive Brachypodium distachyon ecotypes reveals oxidative stress as a major tolerance factor. Sci. Rep. 2016, 6, 27686. [CrossRef]

132. Jackson, M.B.; Armstrong, W. Formation of aerenchyma and the processes of plant ventilation in relation to soil flooding and submergence. Plant Biol. 1999, 1, 274-287. [CrossRef]

133. De Simone, O.; Haase, K.; Muller, E.; Junk, W.J.; Hartmann, K.; Schreiber, L.; Schmidt, W. Apoplasmic barriers and oxygen transport properties of hypodermal cell walls in roots from four Amazonian tree species. Plant Physiol. 2003, 132, 206-217. [CrossRef]

134. Fleck, A.T.; Nye, T.; Repenning, C.; Stahl, F.; Zahn, M.; Schenk, M.K. Silicon enhances suberization and lignification in roots of rice (Oryza sativa). J. Exp. Bot. 2011, 62, 2001-2011. [CrossRef] [PubMed]

135. Soler, M.; Serra, O.; Molinas, M.; Huguet, G.; Fluch, S.; Figueras, M. A genomic approach to suberin biosynthesis and cork differentiation. Plant Physiol. 2007, 144, 419-431. [CrossRef] [PubMed]

136. Ranathunge, K.; Schreiber, L.; Franke, R. Suberin research in the genomics era-new interest for an old polymer. Plant Sci. 2011, 180, 399-413. [CrossRef] [PubMed]

137. Almeida, T.; Menéndez, E.; Capote, T.; Ribeiro, T.; Santos, C.; Gonçalves, S. Molecular characterization of Quercus suber MYB1, a transcription factor up-regulated in cork tissues. J. Plant Physiol. 2013, 170, 172-178. [CrossRef]

138. Gray, W.M. Hormonal regulation of plant growth and development. PLoS Biol. 2004, 2, 306-313. [CrossRef]

139. Wolters, H.; Jürgens, G. Survival of the flexible: Hormonal growth control and adaptation in plant development. Nat. Rev. Genet. 2009, 10, 305-317. [CrossRef]

140. van Veen, H.; Akman, M.; Jamar, D.C.; Vreugdenhil, D.; Kooiker, M.; van Tienderen, P.; Voesenek, L.A.C.J.; Schranz, M.E.; Sasidharan, R. Group VII ethylene response factor diversification and regulation in four species from flood-prone environments. Plant Cell Environ. 2014, 37, 2421-2432. [CrossRef]

141. Sasidharan, R.; Voesenek, L.A.C.J. Ethylene-mediated acclimations to flooding stress. Plant Physiol. 2015, 169, 3-12. [CrossRef]

142. Kumar, S.; Stecher, G.; Tamura, K. MEGA7: Molecular evolutionary genetics analysis version 7.0 for bigger datasets. Mol. Biol. Evol. 2016, 33, 1870-1874. [CrossRef]

143. Yamamoto, F.; Kozlowski, T.T. Regulation by auxin and ethylene of responses of Acer negundo seedlings to flooding of soil. Environ. Exp. Bot. 1987, 27, 329-335, 337-340. [CrossRef]

144. Leyser, O. Auxin signaling. Plant Physiol. 2018, 176, 465-479. [CrossRef] [PubMed]

145. Verstraeten, I.; Beeckman, T.; Geelen, D. Adventitious root induction in Arabidopsis thaliana as a model for in vitro root organogenesis. Methods Mol. Biol. 2013, 959, 159-175. [PubMed]

146. Agulló-Antón, M.Á.; Ferrández-Ayela, A.; Fernández-García, N.; Nicolás, C.; Albacete, A.; Pérez-Alfocea, F.; Sánchez-Bravo, J.; Pérez-Pérez, J.M.; Acosta, M. Early steps of adventitious rooting: Morphology, hormonal profiling and carbohydrate turnover in carnation stem cuttings. Physiol. Plant. 2014, 150, 446-462. [CrossRef] [PubMed]

147. Gutierrez, L.; Bussell, J.D.; Pacurar, D.I.; Schwambach, J.; Pacurar, M.; Bellini, C. Phenotypic plasticity of adventitious rooting in Arabidopsis is controlled by complex regulation of AUXIN RESPONSE FACTOR transcripts and microRNA abundance. Plant Cell 2009, 21, 3119-3132. [CrossRef] 
148. Gutierrez, L.; Mongelard, G.; Flokova, K.; Pacurar, D.I.; Novak, O.; Staswick, P.; Kowalczyk, M.; Păcurar, M.; Demailly, H.; Geiss, G.; et al. Auxin controls Arabidopsis adventitious root initiation by regulating jasmonic acid homeostasis. Plant Cell 2012, 24, 2515-2527. [CrossRef]

149. Fukao, T.; Bailey-Serres, J. Submergence tolerance conferred by Sub1A is mediated by SLR1 and SLRL1 restriction of gibberellin responses in rice. Proc. Natl. Acad. Sci. USA 2008, 105, 16814-16819. [CrossRef]

150. Ikeda, A.; Ueguchi-Tanaka, M.; Sonoda, Y.; Kitano, H.; Koshioka, M.; Futsuhara, Y.; Matsuoka, M.; Yamaguchi, J. slender rice, a constitutive gibberellin response mutant, is caused by a null mutation of the SLR1 gene, an ortholog of the height-regulating gene GAI/RGA/RHT/D8. Plant Cell 2001, 13, 999-1010.

151. Itoh, H.; Ueguchi-Tanaka, M.; Sato, Y.; Ashikari, M.; Matsuoka, M. The gibberellin signaling pathway is regulated by the appearance and disappearance of SLENDER RICE1 in nuclei. Plant Cell 2002, 14, 57-70. [CrossRef]

152. Itoh, H.; Shimada, A.; Ueguchi-Tanaka, M.; Kamiya, N.; Hasegawa, Y.; Ashikari, M.; Matsuoka, M. Overexpression of a GRAS protein lacking the DELLA domain confers altered gibberellin responses in rice. Plant J. 2005, 44, 669-679. [CrossRef]

153. Fukao, T.; Xu, K.N.; Ronald, P.C.; Bailey-Serres, J. A variable cluster of ethylene response factor-like genes regulates metabolic and developmental acclimation responses to submergence in rice. Plant Cell 2006, 18, 2021-2034. [CrossRef]

154. Ueguchi-Tanaka, M.; Ashikari, M.; Nakajima, M.; Itoh, H.; Katoh, E.; Kobayashi, M. GIBBERELLIN INSENSITIVE DWARF1 encodes a soluble receptor for gibberellin. Nature 2005, 437, 693-698. [CrossRef] [PubMed]

155. Du, H.; Chang, Y.; Huang, F.; Xiong, L.Z. GID1 modulates stomatal response and submergence tolerance involving abscisic acid and gibberellic acid signaling in rice. J. Integr. Plant Biol. 2015, 57, 954-968. [CrossRef] [PubMed]

156. Zhou, X.; Zhang, Z.L.; Park, J.; Tyler, L.; Yusuke, J.; Qiu, K. The ERF11 transcription factor promotes internode elongation by activating gibberellin biosynthesis and signaling. Plant Physiol. 2016, 171, 2760-2770. [CrossRef] [PubMed]

157. Dubois, V.; Moritz, T.; Garcia-Martinez, J.L. Comparison of the role of gibberellins and ethylene in response to submergence of two lowland rice cultivars, Senia and Bomba. J. Plant Physiol. 2011, 168, 233-241. [CrossRef] [PubMed]

158. Jackson, M.B.; Hall, K.C. Early stomatal closure in waterlogged pea-plants is mediated by abscisic-acid in the absence of foliar water deficits. Plant Cell Environ. 1987, 10, 121-130.

159. Zhang, J.; Van Toai, T.; Huynh, L.; Preiszner, J. Development of flooding-tolerant Arabidopsis thaliana by autoregulated cytokinin production. Mol. Breed. 2000, 6, 135-144. [CrossRef]

160. Nguyen, T.N.; Tuan, P.A.; Mukherjee, S.; Son, S.; Ayele, B.T. Hormonal regulation in adventitious roots and during their emergence under waterlogged conditions in wheat. J. Exp. Bot. 2018, 69, 4065-4082. [CrossRef]

161. Kim, Y.H.; Hwang, S.J.; Waqas, M.; Khan, A.L.; Lee, J.H.; Lee, J.D.; Nguyen, H.T.; Lee, I. Comparative analysis of endogenous hormones level in two soybean (Glycine max L.) lines differing in waterlogging tolerance. Front. Plant Sci. 2015, 6, 714. [CrossRef]

162. Schmitz1, A.J.; Folsom, J.J.; Jikamaru, Y.; Ronald, P.; Walia, H. SUB1A-mediated submergence tolerance response in rice involves differential regulation of the brassinosteroid pathway. New Phytol. 2013, 198, 1060-1070. [CrossRef]

163. Chen, H.J.; Qualls, R.G.; Blank, R.R. Effect of soil flooding on photosynthesis, carbohydrate partitioning and nutrient uptake in the invasive exotic Lepidium latifolium. Aquat. Bot. 2005, 82, 250-268. [CrossRef]

164. Colmer, T.D.; Bloom, A.J. A comparison of $\mathrm{NH}_{4}{ }^{+}$and $\mathrm{NO}_{3}{ }^{-}$net fluxes along roots of rice and maize. Plant Cell Environ. 1998, 21, 240-246. [CrossRef]

165. Armstrong, J.; Armstrong, W. Rice: Sulfide-induced barriers to root radial oxygen loss, $\mathrm{Fe}^{2+}$ and water uptake, and lateral root emergence. Ann. Bot. 2005, 96, 625-638. [CrossRef] [PubMed]

166. Tan, S.D.; Zhu, M.Y.; Zhang, Q.F. Physiological responses of bermudagrass (Cynodon dactylon) to submergence. Acta Physiol. Plant. 2010, 32, 133-140. [CrossRef] 